\title{
The Twisting Paths of Recall: Khipu (Andean cord notation) as artifact
}

\author{
Frank Salomon \\ University of Wisconsin-Madison
}

The most complex system of writing (using the word in a broad sense) that Andean peoples possessed before the Spanish invasion of 1532 was the cord- and knot-based medium called khipu (Quechua) or quipu (Spanish). The material makeup of khipu is a story of variation over time, with some longue durée continuities. Khipu had a brief, spectacularly productive heyday as the official medium of the Inka state (established some time during the $15^{\text {th }}$ century CE until $1532 \mathrm{CE}$ ). The great majority of all the 600-odd more or less complete khipus held in museums and accessible private collections are catalogued as imperial Inka artifacts, but new radiocarbon results show that some date from the Spanish colony (Cherkinsky and Urton, forthcoming). The Ethnologisches Museum in Berlin and the American Museum of Natural History in New York have the largest collections. Online offerings suggest that an unknown number of them (some fake) are in other hands. Inka khipus were largely standardized in format and material content (Figure 1).

But Inkas are not the only principals in this story. The cord medium underwent a long, varied evolution both before and after khipus' brief Inka florescence. Both pre- and post-Inka khipus differed widely from Inka ones in physical substance and form. This chapter consists of a historical and a functional section. In the first half I discuss material attributes of Inka, pre-Inka, and post-Inka khipus, respectively, with emphasis on change. By contrast, in the second half of this chapter I emphasize material continuity: material traits that make a khipu a khipu, and how they affect culture as lived through inscription. For the spatial distribution of the evidence discussed, see the map in Figure 2.

\section{Recent Research Historical Variation in Khipu \\ Material Support of Meaning in the Inka Canon}

Inka-era khipus' physical characteristics as substrate for meaning have been the object of intense study since the 1920s, largely by archaeologists hosted in museums. Inka khipus are

\section{How to cite this book chapter:}

Salomon, F. 2013. The Twisting Paths of Recall: Khipu (Andean cord notation) as artifact. In: Piquette, K. E. and Whitehouse, R. D. (eds.) Writing as Material Practice: Substance, surface and medium. Pp. 15-43. London: Ubiquity Press. DOI: http://dx.doi.org/10.5334/bai.b 


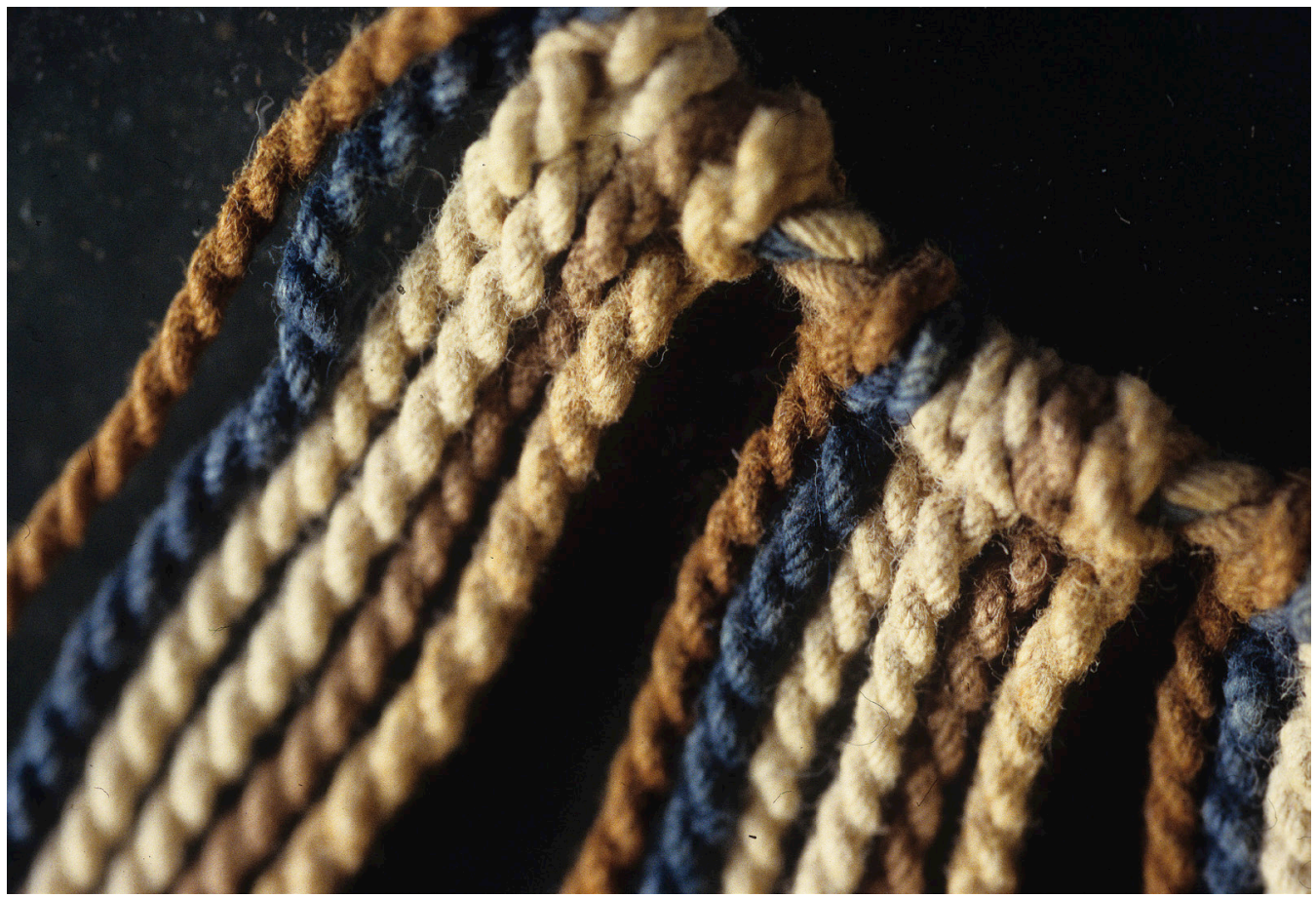

Figure 1: Khipu demonstrates repeating colour sequence. 64-19-1-1-6-2 of the Musée de l'Homme (now in Musée du Quai Branly).

overwhelmingly made of cotton, but a few camelid wool examples survive (Conklin 2002: 61). The predominance of cotton may just be an artifact of better preservation on the cotton-using desert coast. Early colonial sources with Inka informants usually mention camelid wool as the common medium. Basic Inka khipu structure (Figure 3) consists of a main cord to which knottable pendant cords were fixed by half-hitches. Pendants are frequently grouped in sets of $n$ cords, with spaces between them. Often, a group contains a repeating sequence of colors. But the alternative - colors occurring in bands - is also common. In this author's opinion the two patterns reflect complementary genera, such as planning / execution. Pendant fiber is usually of natural color (Peruvian cotton being of varied hue in the white-to-dark brown range), but dyed colors (particularly blue) occur. At least three separate techniques were used to create bi-colored or multicolored pendants: a 'barber pole' pattern of spirals, a mottled pattern, and a type in which a single cord changes color along its course.

Especially in main cords, plying may be complex. Occasionally a bright-colored thread is 'run through' as supplementary ply, acting to 'underline' a cord. Pendants may carry subsidiary pendants as in Figure 4, and subsidiaries in turn may carry sub-subsidiaries, etc. Registries may be several hierarchical layers deep. Knots were normally of only three types (Figure 5). It is now over 80 years since Leland Locke $(1923$; 1928) discovered how the three types were deployed in decimal arrays, encoding arithmetical relationships. The pioneering khipu experts Marcia and Robert Ascher argue that about $80 \%$ of khipu are numerical. A pendant normally bears a single number expressed in base-10 positional notation (Figure 6). Sometimes special pendants called top cords contain summations over pendants.

Locke's work, however, left out of account almost all properties except knots. A surge of research beginning in 1990 has striven to change this situation. The point of departure was Ascher and Ascher's massive 1981 study of museum khipus (republished 1997: 57). The Aschers emphasized 




Figure 2: Map showing main locations mentioned in the text.

"Inca insistence" on "spatial arrangements [that] use formal repetition and recombination of basic elements": in other words, that the combinations of knots signaling numbers are only parts of larger combinatorial structures.

The textile archaeologist William Conklin concentrates on the material basis of such structures. He has revisited khipu structure with a maximalist hypothesis, cognate to Urton's model (2003) about how many features might bear coded meaning. Beyond knotting, he also considers colors, color combinations, S / Z (rightward versus leftward), plying, S / Z knotting, and 'obverse / reverse' (also called 'recto / verso') placement of pendants' attachment loops. The maximalist approaches of Conklin and Urton have greatly increased the number of potentially recognizable patternings, and with it the quantity of information khipus could plausibly be supposed to hold. Estimating six data-bearing variables (of which one is a knotted number up to 10,000), and calculating the number of possible data-states they allow, Conklin calculated that "each...secondary cord [i.e. pendant] could theoretically hold...8 million differing combinations or states" (Conklin 2002: 81). Where the line between 'emically' meaningful variation and variation in sub-meaningful material support lies, remains a fundamental question. 


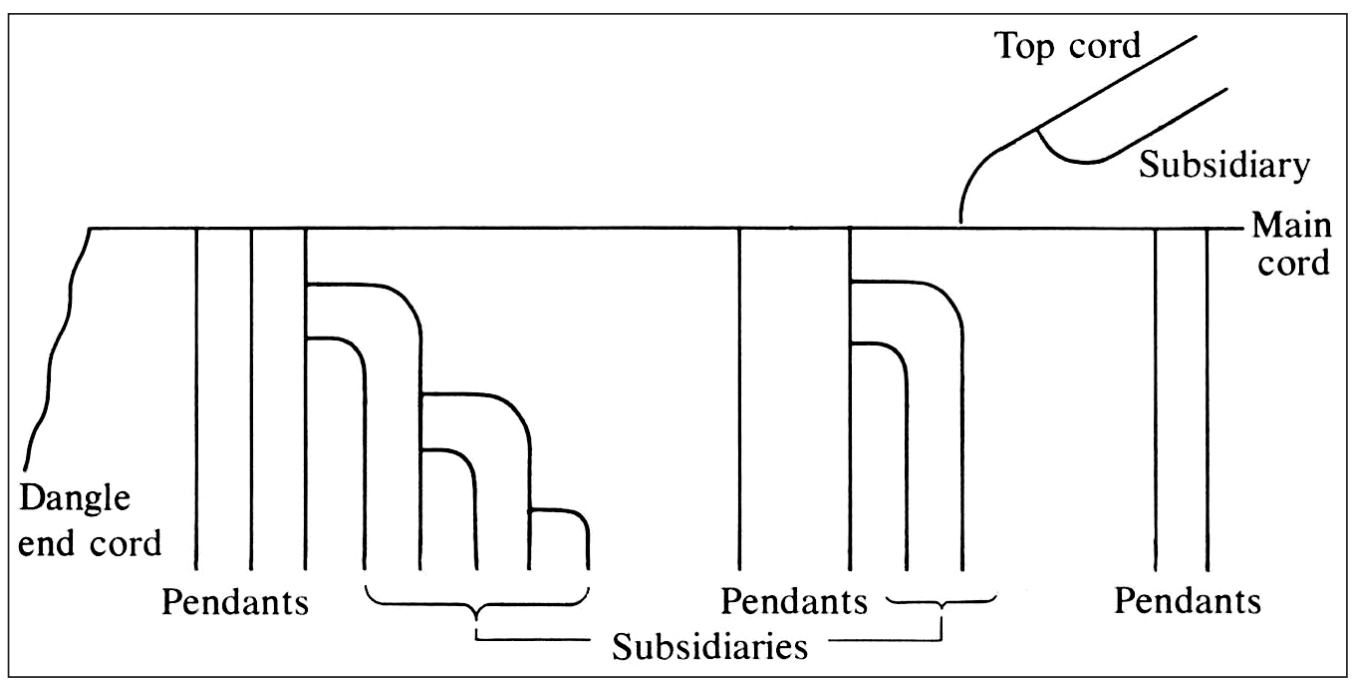

Figure 3: Basic khipu terminology and structure (Ascher and Ascher 1997: 12, fig. 2.7). By permission of Marcia Ascher and Robert Ascher.

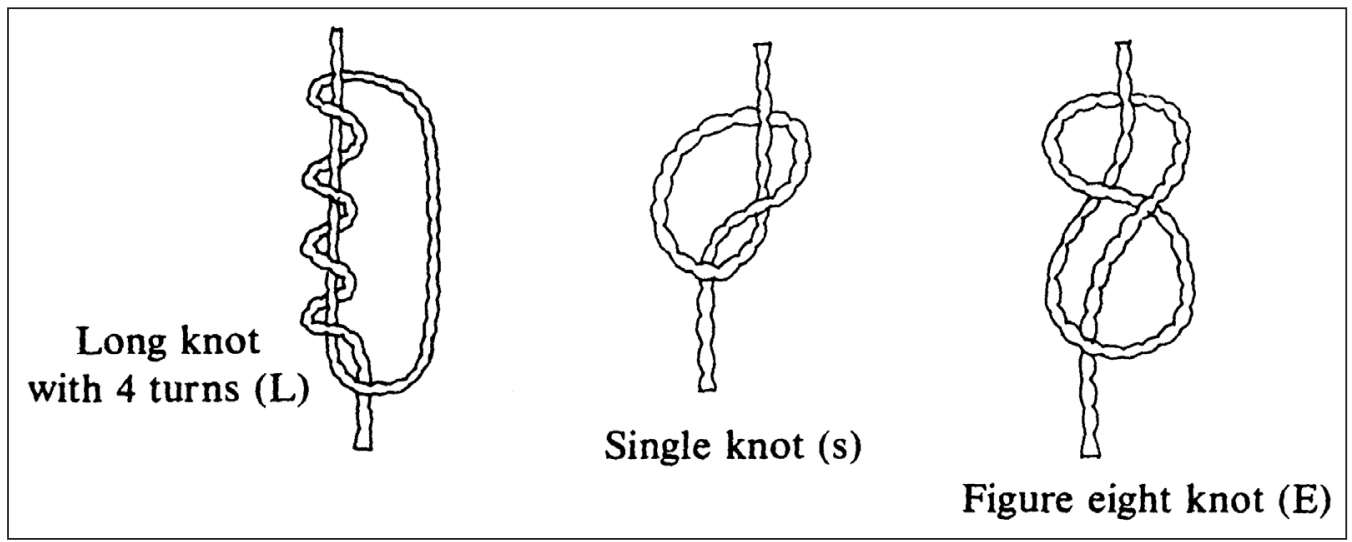

Figure 4: Three common knots used in Inka khipus: Left: Inka long knot of value four, used in units place; center, simple (s) knot; right, figure-eight (E) knot (Ascher and Ascher 1997: 29, fig. 2.11). By permission of Marcia Ascher and Robert Ascher.

In the course of a vast continuing study which has almost tripled the number of Inka khipus under study at the time of the Aschers' book (1997 [1981]), Gary Urton formulated a more precise model of the relation between cord structures and encoded meanings. He holds that inherently dualistic processes of spinning and plying (over / under, left / right) are congenial analogues for Native South American cultures' pervasive cultural binarism (Urton 2003: 149-151). Andean societies prefer dual models for many sorts of organization: 'high' and 'low' moieties, left / right bank settlements, senior / junior lineages, dry/wet semesters, mountainside / valleyside lands, male / female cults. Such binarisms are not simple symmetries but have an element of markedness / unmarkedness in the linguistic sense. I have previously characterized such pairings as "symmetrical in form, complementary in function, and unequal in rank" (Salomon 2004: 192). Andean anthropologists generally agree that the pairing of many things and roles reflects a general cultural template. From Inka to modern times whole khipus have been made in sets of two (Figure 7, see also Figure 20). 


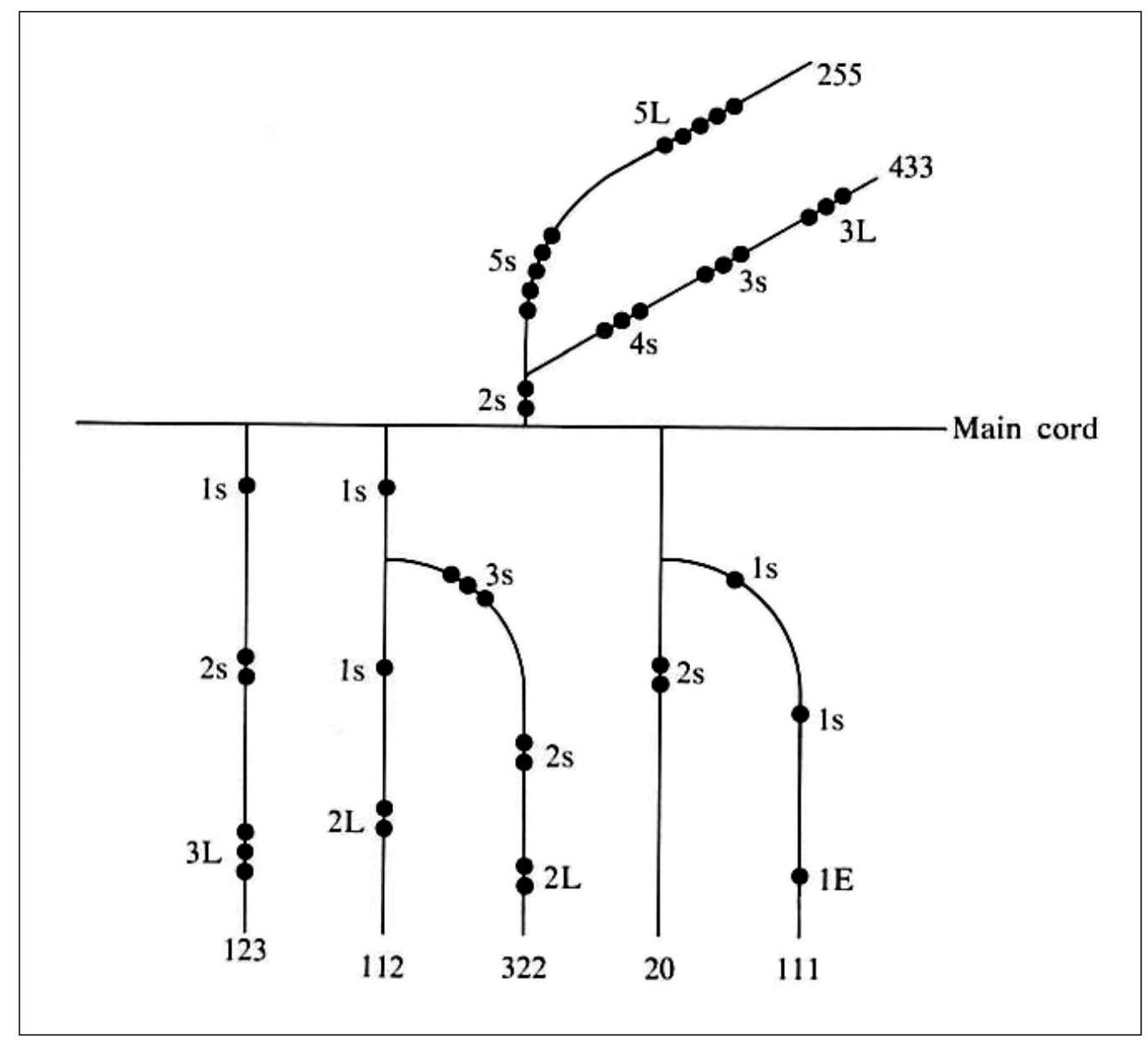

Figure 5: A khipu with arithmetical values. The topcord sums the values of pendants, and the topcord's subsidiary those of the pendants' subsidiaries (Ascher and Ascher 1997: 31, fig. 2.14). By permission of Marcia Ascher and Robert Ascher.

For Urton, a sequence of seven binary manufacturing operations, of which knotting is only the last, produces cords. Each step involves a choice between dual alternatives, e.g. cotton versus wool fiber (with wool as marked) or S / Z (rightward versus leftward) final plying (with Z as marked). The seven, in sequence, are 1) choice of fiber; 2) choice of colors considered as choice between two locally conceived spectra; 3) S / Z final plying; 4) recto / verso pendant attachment; 5) S / Z knotting; 6) 'number class' (a variable constructed upon an Andean model of complete / incomplete numbers); 7) decimal / non-decimal 'information type' (Urton 2003: 120). Thus, he holds, any given pendant constitutes a 'seven-bit' data aggregate.

Inka khipu code, he therefore argues, is made of such data-chunks materially incarnated in fiber, much as ASCII computer code is made of eight-bit groups of 0 s and 1s materialized as bands of magnetized / demagnetized surface. Meaningfulness is not knotted onto a blank cord; the sum of all the cord's attributes determines its meaning. The inventory of possible seven-bit cords is, however, not in itself a code. Rather it makes up an array of related physical forms which become a code when meanings are assigned to each. Meaning may have been assigned in variable ways. 


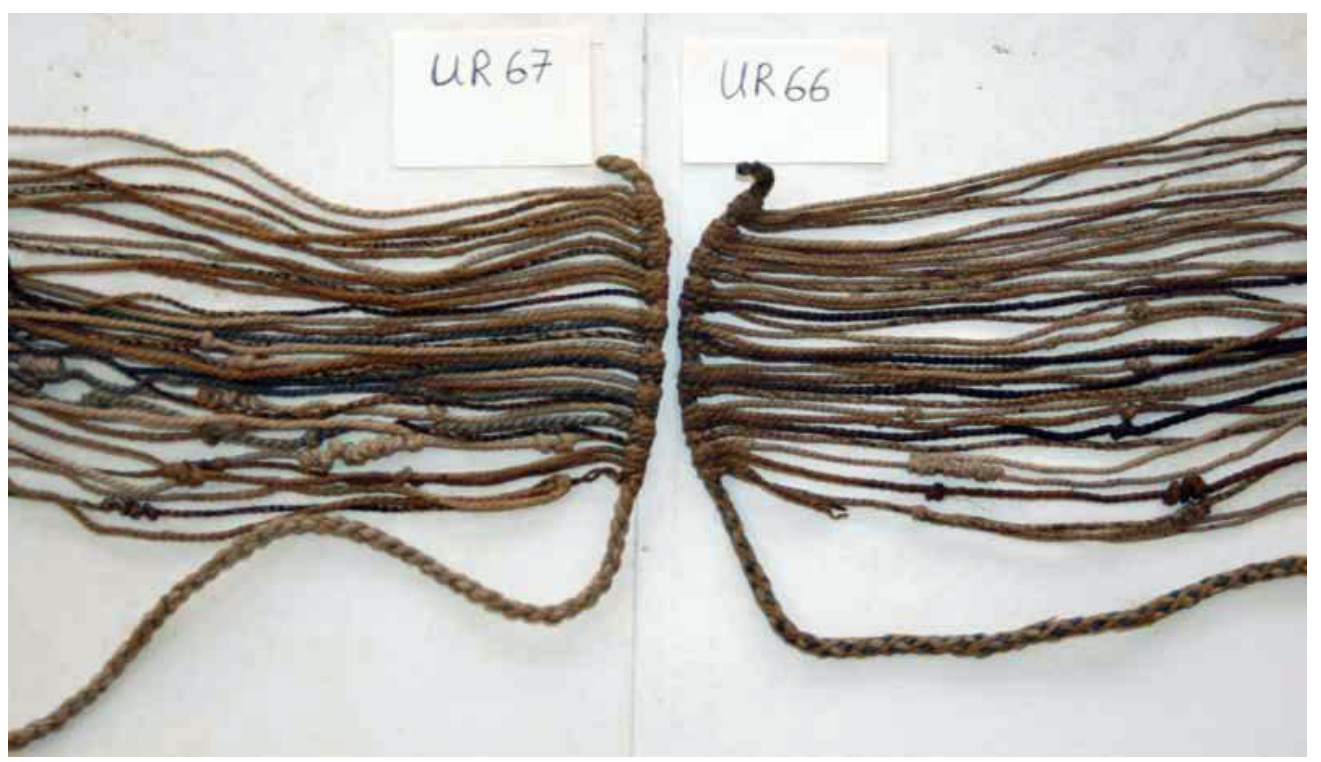

Figure 6: Paired khipu from Puruchuco: these two Inka-era specimens (UR 66-67) were rolled together, and bear similar color patterning. Photograph courtesy of Gary Urton.

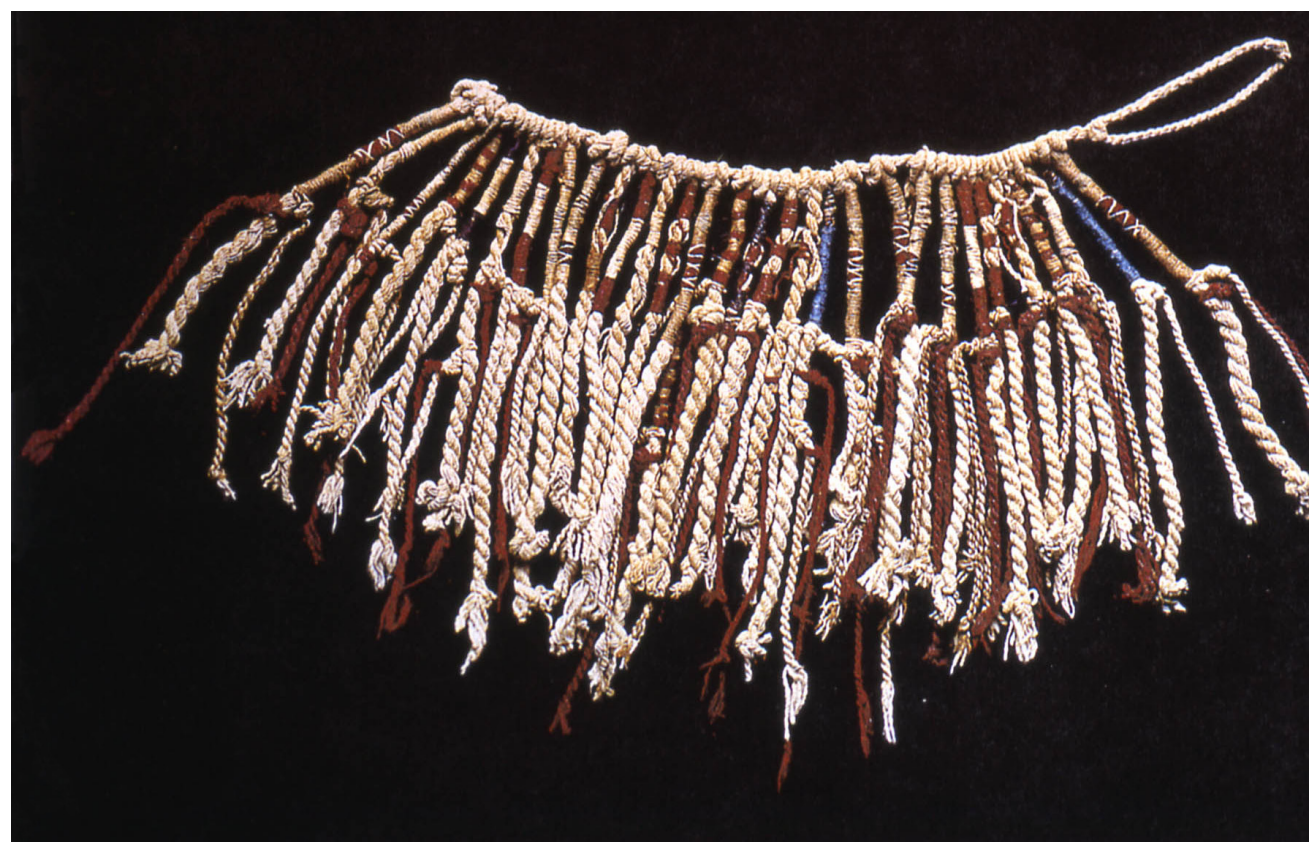

Figure 7: Khipus of Wari affiliation, several centuries earlier than Inka examples, bear information in the form of colored thread lashed around pendant cords. American Museum of Natural History T-223. Photograph courtesy of Carmen Arellano.

Much as eight-bit bundles of 0 s and 1 s can be programmed to stand for alphabetic characters, but equally well for colors or sounds, a cord might well be coded to stand for a word (and thus become a logogram); but it might equally well be coded to a nonverbal entity. 


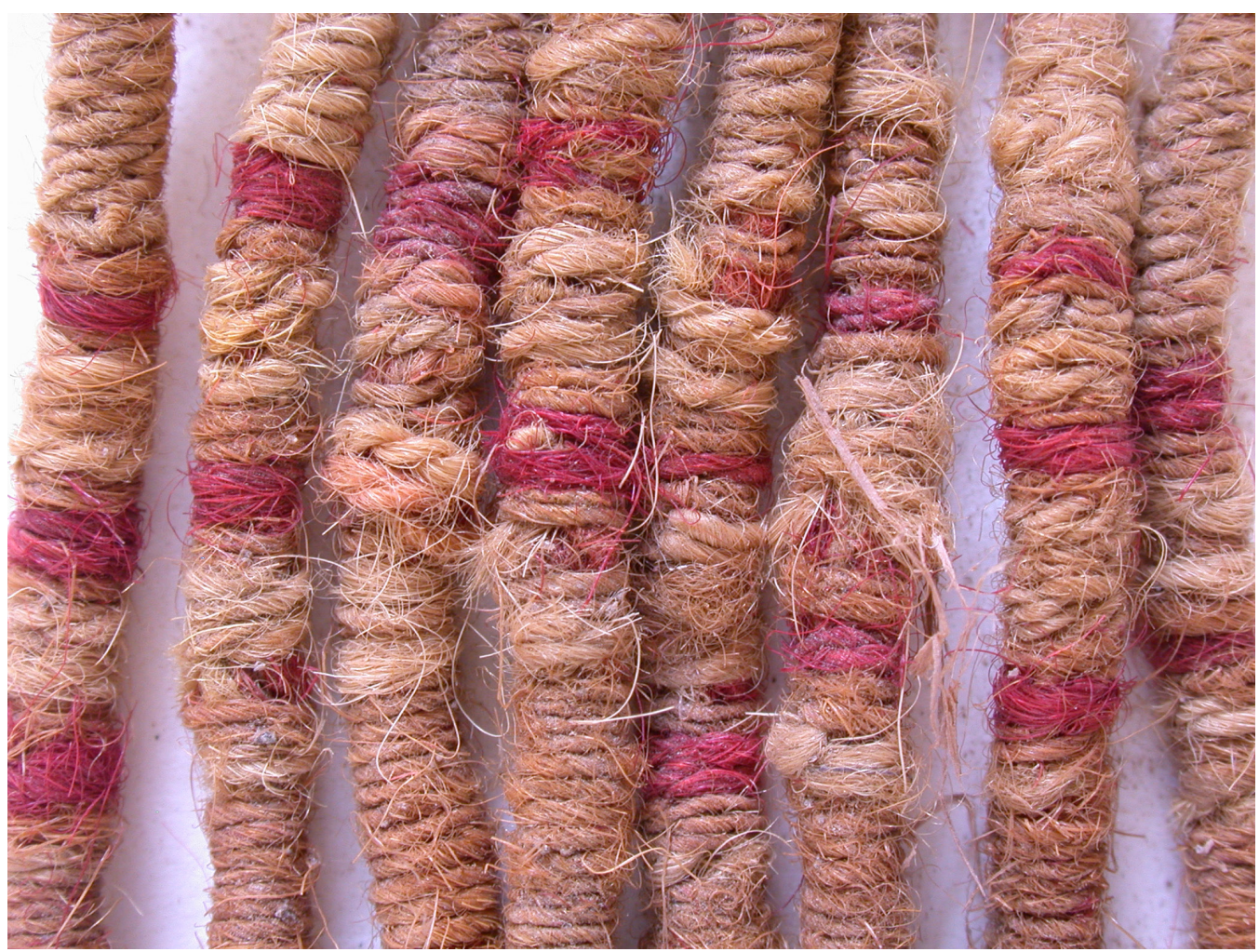

Figure 8: Wrapped sticks from funerary context at the Paracas site of Cerrillos. Photograph courtesy of Jeffrey Splitstoser.

Thus Urton's model is more a model about how cords can mean, than about what they mean. On those terms, it has proven productive. Urton has shown that previously unstudied physical variables do in some specimens obey non-random patterns which all but certainly were made to convey a meaning. For example in one case (Urton 2003: 87), the maker of a khipu divided it into four quadrants, two of which use Z-knots and the other two S-knots. Was this a 'meta' feature, like punctuation, which shows a user how to voice or interpret the data? Or was it a direct classification of the referents into four subsets, forming pairs among themselves, within the dataset? We do not know. But the maximalist hypothesis about how many Inka khipu features are significant, i.e. contribute to sign value, is now known to yield patterned Inka complexities above and beyond arithmetical patterns.

\section{Before the Inka Canon: Wrapping and knotting for the dead and the living}

Up to this point I have commented only on canonical Inka-type khipus. But it has become evident that, like many of the culture traits which the Inkas falsely claimed as their own inventions, khipu had a long and varied pre-Inka history. In this matter, too, William Conklin has made a decisive contribution. In 1982 he showed that about 700 years before the Inka conquests began, khipus had already reached an elaborate - but very different - physical format (see Figure 7). One corpus consists of eight fragmentary khipus found with a Wari culture mummy at Pampa Blanca on the south coast of Peru. The burial is dated about $700 \mathrm{CE}$ on ceramic criteria. Similar specimens have less clear context. 
Wari, an expansive culture associated with a southern Peruvian state of possibly imperial makeup, was one of two cultures that characterize the period of far-flung cultural sharing called the Middle Horizon. Conklin identified three material peculiarities: first, "the shanks of the pendant cords are wrapped with patterned multicolored thread" (Conklin 1982: 268); second, knotting is less salient and varied: the only knots are multiple overhand knots; third, final plying is uniformly Z. Two more unprovenanced khipus, each small enough to fit in one hand but richly crafted, belong to the same type. Their thread lashings are bright-colored and complexly patterned with color bars and Xs. Both subsidiaries and knots, in contrast, are much less frequent than in Inka examples. Conklin describes a final, large and remarkable thread-wrapped khipu with 100 pendants in groups of five, and 10 different types of subsidiaries hanging from them. Conklin (1982: 277) suggests that the numerical system is base five.

Long before the Inkas, then, Middle Horizon khipu seem to have had a different material constitution. It corresponded to an exalted use, as we know from their treasure-grade craftspersonship. One equally luxurious specimen seems transitional between the Middle Horizon and Inka khipus (Pereyra 1997). The Inkas held Middle Horizon remains in reverence as 'prototypes' (dechados; Betanzos 1987 [1551]: 11-13) of their world, and may have viewed thread-wrapping as a sign of archaic glory. If they associated wrapping with remote antiquity they were not mistaken, for this practice appears in textiles of a cultural horizon very much older than even the Middle Horizon: that is, the Chavín or Early Horizon, about 1000 вСЕ.

There is another Andean medium that emphasizes wrapping. Thread-wrapping of sticks had a two-millennium life alongside thread-wrapping of khipus. Jeffrey Splitstoser has studied fourcolor Chavín-influenced wrapped sticks from the Paracas site of Cerrillos (Conklin and Splitstoser 2009; see Figure 8). They accompanied a female burial dating to about 200 BCE. Imagery of birds carrying such sticks ranges from Chavín through Middle Horizon chronology. Numerous wrapped sticks of immediately pre-Inka, Inka, or immediately post-Inka times are preserved in museums (see Figure 9). Herrmann and Meyer (1993) have published astonishing images of late prehispanic mummies holding wrapped sticks (see Figure 10).

What do wrapped sticks have to do with mummies? Miguel Cabello Valboa, a chronicler who had access to local native informants (Núñez-Carvallo 2008: 92), among them the half-Inka Jesuit Blas Valera, states that the last prehispanic Inka sovereign, when he felt death approaching, "made his testament as was the custom...putting lines [rayas] with different colors on a stick, from which they knew his last and final will, and which was given in care to a khipu master" (Cabello Valboa 1951 [1586]: 393).

It seems, therefore, that a very ancient, elaborate thread-wrapping medium belonged to funerary culture, perhaps holding directives for the permanent ritual treatment of the ancestor. Middle Horizon khipu may have been born when another, knot-based medium was combined with it. The origin of the knotting medium is unknown. Ruth Shady et al. (2000) identifies a knotted object from Caral on the Pacific coast as a khipu at least 3000 years old (Mann 2005: 1008), but other archaeologists have yet to confirm the identification. On less controversial grounds Shady et al. (2000) also show a knotted specimen c.650-750 CE from Lima, roughly contemporary with Conklin's (1982) thread-wrapped type.

\section{After the Inka Canon: The khipu - paper interface and its modern successors}

Contrary to what one reads in classics of grammatology, khipus had a vigorous continuing history in the colonial era (Salomon 2008). Khipu use up to about $1600 \mathrm{CE}$ has been well researched, most comprehensively by Pärssinen and Kiviharju (2004), and also by historians such as Sempat Assadourian (2002), de la Puente Luna and Curátola (2008), and Loza (1998). 


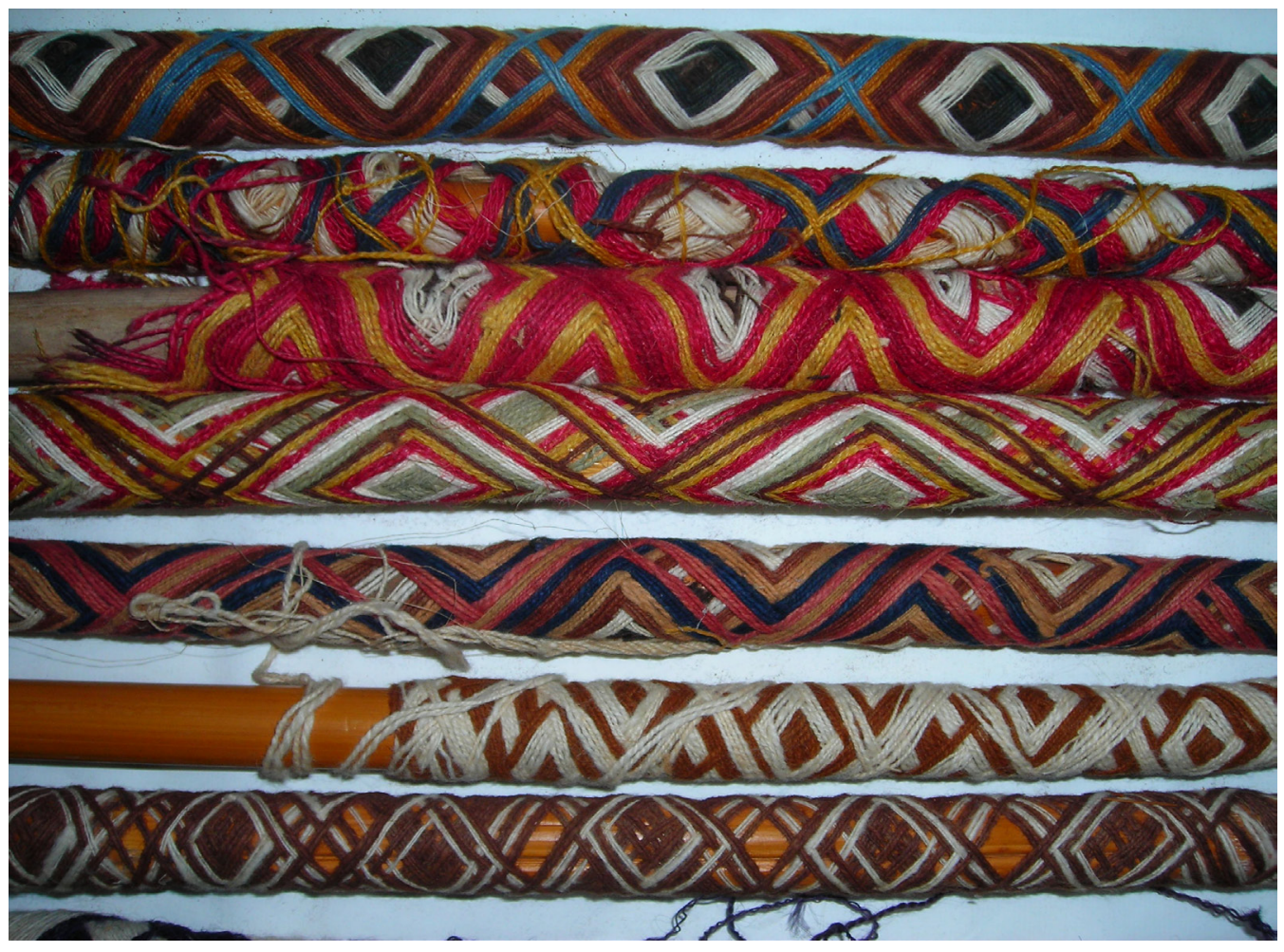

Figure 9: Wrapped sticks of late prehispanic and / or colonial dates in the collection of the Peabody Museum, Harvard. Photograph courtesy of William Conklin.

The transition from early, unstable, improvised colonial governance to the bureaucratic regime associated with Viceroy Toledo (1569-1581) also brought a transition in the information technology of empire. As a small ethnic minority in a multilingual empire thousands of kilometers long and inhabited by millions, Spaniards were at first dependent on khipu-based information flows to set up their colonial state. Spaniards from the 1530s through the 1550s relied upon khipu masters for accounting of native tribute and labor. In the 1560s they came to systematically integrate cord records with the production of new administrative papers. There arose a system of articulation between the khipu art and what the Uruguayan humanist Angel Rama (1996 [1984]) called "the lettered city" of Hapsburgian scribes and notaries. Well before 1569 Spanish courts and tribute administrators were accustomed to accepting khipu-based information as evidence in lawsuits and tribute proceedings (even though the Council of the Indies never authorized this). After 1569, in the age when reducción (forced resettlement) and the new political establishment of 'Indian cabildos' (village councils) came to counterweight the power of prehispanically-derived local dynasties, colonial governance did much more than passively take note of khipus. Spanish functionaries actively required villages to make and present administrative khipus. Lawyers, scribes, and notaries created a specific protocol governing the interface between intra-indigenous and imperial information conduits (Burns 2004). ${ }^{1}$

Although C14 dates of museum khipus sometimes overlap the conquest era, no museum collection has been radiocarbon dated exclusively to the colonial era. We do not yet know what material traits may correspond specifically to the colonial cord - paper interface. Urton (2001) has persuasively interpreted one specimen found in context of a post-hispanic mummy as an account of 


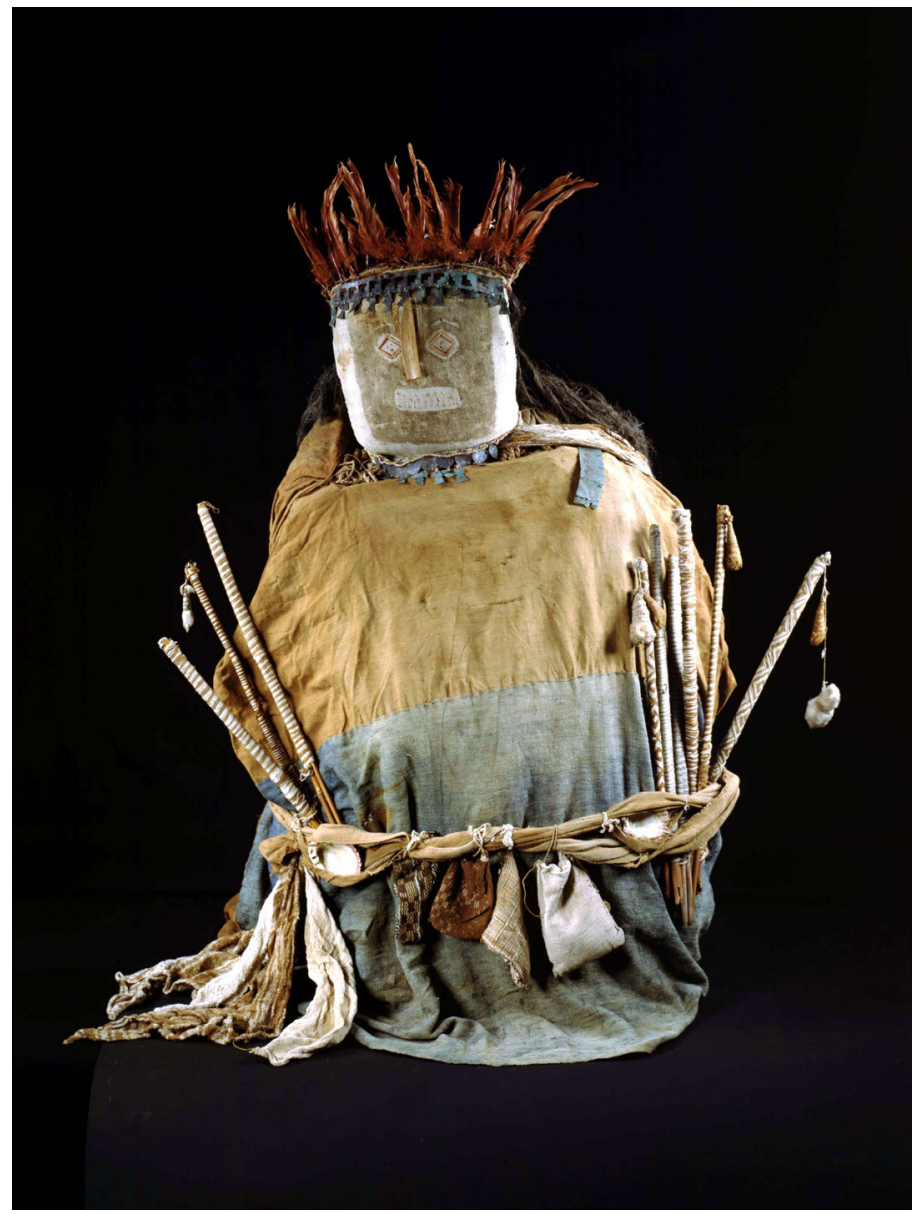

Figure 10: Mummy from Chuquitanta with wrapped sticks. Photograph courtesy of Berndt Herrmann.

colonial tributes of the 1560s; in material makeup it resembles Inka work, with peculiarities that are more likely regional than chronological.

Early in the $17^{\text {th }}$ century Spanish judges stopped admitting khipu masters to official functions. Increasingly, the khipu art apparently lodged in folk-legal proceedings off the colonial ledger. In the course of three colonial centuries, khipu shifted from being the Andean politico-administrative medium par excellence, to being very local, intracommunal records created in a sphere of cultural privacy.

After independence (various dates of the 1820s in different republics), creole states recognized no specifically 'Indian' authorities as such. Now no pan-Andean khipu user community existed. Khipus were shown to outsiders mostly in the course of administering private latifundist estates. Max Uhle in 1897 published the first full description of an 'ethnographic khipu', a herder's log of animals from Cutusuma, Bolivia. Several other $20^{\text {th }}$-century reports describe herding khipus (Nuñez del Prado 1990 [1950]; Prochaska 1988; Soto Flores 1990 [1950-1951]), one from as far afield as Ecuador (Holm 1968).

Such ethnographically known khipus are the best understood ones, because in these encounters researchers were able to discuss individual khipus with their makers and users. In 2002 I interviewed several families near the northern and western shores of lake Titicaca, some Quechuaphone 




Figure 11: A herder's khipu from modern Peru, studied by Carol Mackey in the late 1960s (in Quilter and Urton 2002: 334). It analyzes a herd of llamas by reproductive status.

and others Aymarophone, about recent memories of the khipu art. Their elders could still simulate khipus made to track household properties: private herds, harvests, debts, and pending obligations. They described household khipus as small khipus which would usually be pegged to a wall, either inside the house for privacy or outside, under the eaves, for daytime convenience. All 'ethnographic' khipus are of wool.

What stands out in such 'ethnographic' khipus is their nonstandard physical makeup. Carol Mackey's important but still incompletely published 1970 study of 24 modern specimens, some of whose owners were still competent in the art, uncovered "great variability in morphology and in numeral notation" (Mackey 2002: 324), including one major class without a main cord to suspend pendants (see Figure 11), and another with a main cord. In the former, a data-bearing cord is bent in a ' $U$ ' and lashed to form a two-tailed armature for attaching smaller cords. Besides morphology, another general problem of khipu design is at its most visible in modern 'ethnographic' khipus: iconicity. Some 'herders' khipus' include small non-cord objects in knots. Prochaska (1983) reports that Taquile Island khipus included wood bits taken as iconic of individual animals and their condition. A few Inka specimens have tuft inclusions, as do all Rapaz specimens (see concluding section). Whether inclusions should be understood under the rubric of index, icon, or logogram remains an important issue. 


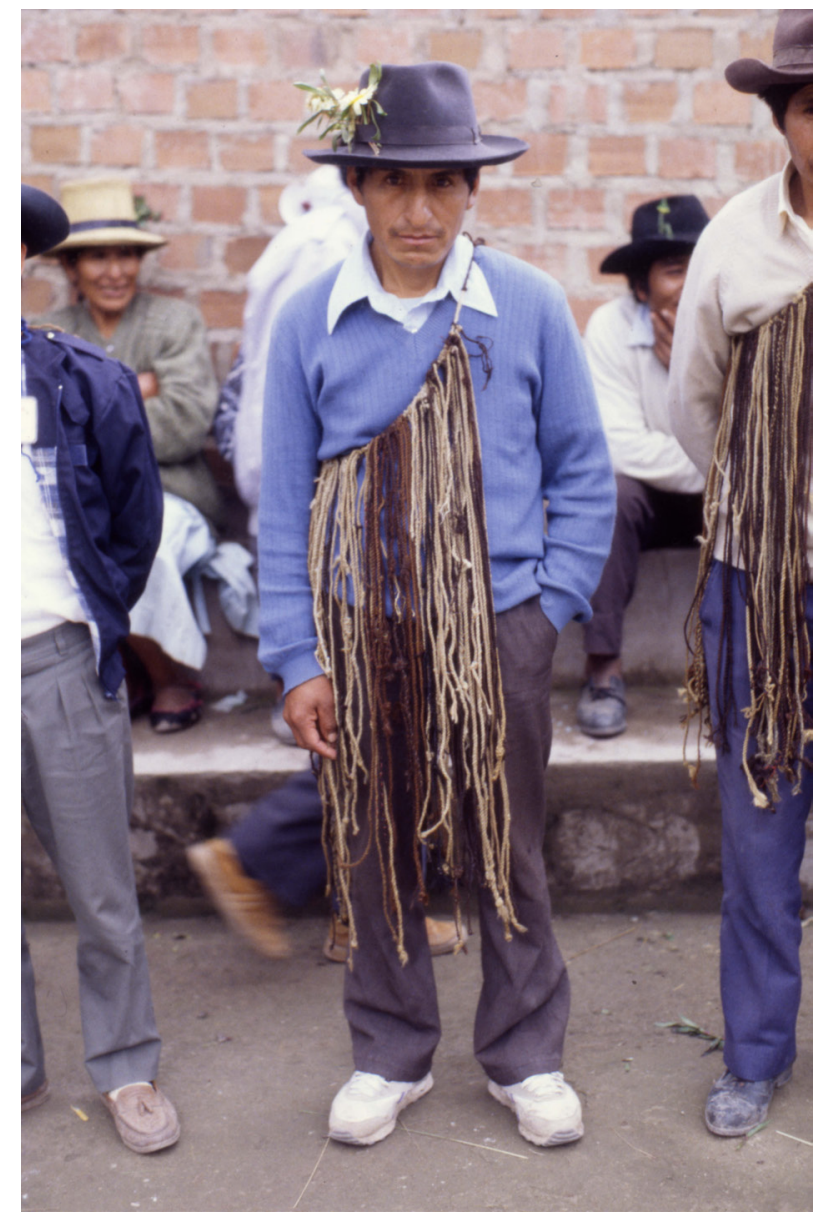

Figure 12: In Tupicocha, Peru, 1995, Celso Alberco assumed the presidency of his ayllu (a network of families) by donning its khipu. Author's photograph.

Not all the modern forms of khipu, however, derive from the private sphere. Modern khipus of governance do exist, at village rather than state level. In the early $19^{\text {th }}$ century, decades of weak republican administration (Thomson 2002: 269-280) gave communities in some provinces a chance to invigorate local Andean institutions of government. Some chose to prolong the use of khipu in self-administration. In a few cases, these have survived as patrimony of peasant communities, or their components, the segmentary corporate lineages called ayllus. Like herders' khipus, they show wide divergences in structure, as one might expect in situations of local cultural privacy. All originate in high-altitude villages (over $3000 \mathrm{~m}$ above sea level), and all are of wool.

A few such 'patrimonial khipus' have been studied in material detail. The most fully published patrimonial case is that of Tupicocha, in Huarochirí, Peru. Tupicocha owns 10 historical khipus (Salomon 2004; Figure 12) and one recently made simulacrum to replace a lost one. From 1994 to the 2009 writing of this chapter, no-one claimed competence in reading khipus. The village holds them in reverence, and uses them as regalia in the annual 'town meeting' at which authorities render accounts for money and works. The actual records are now made on paper, but the quipocamayos or caytus are presented as their former and forever-valid prototypes.

Tupicochan khipus are of medium size. In overall design they closely resemble the canonical Inka type (Figure 13). They show little if any of the 'reduction' or 'defectiveness' characteristic of 


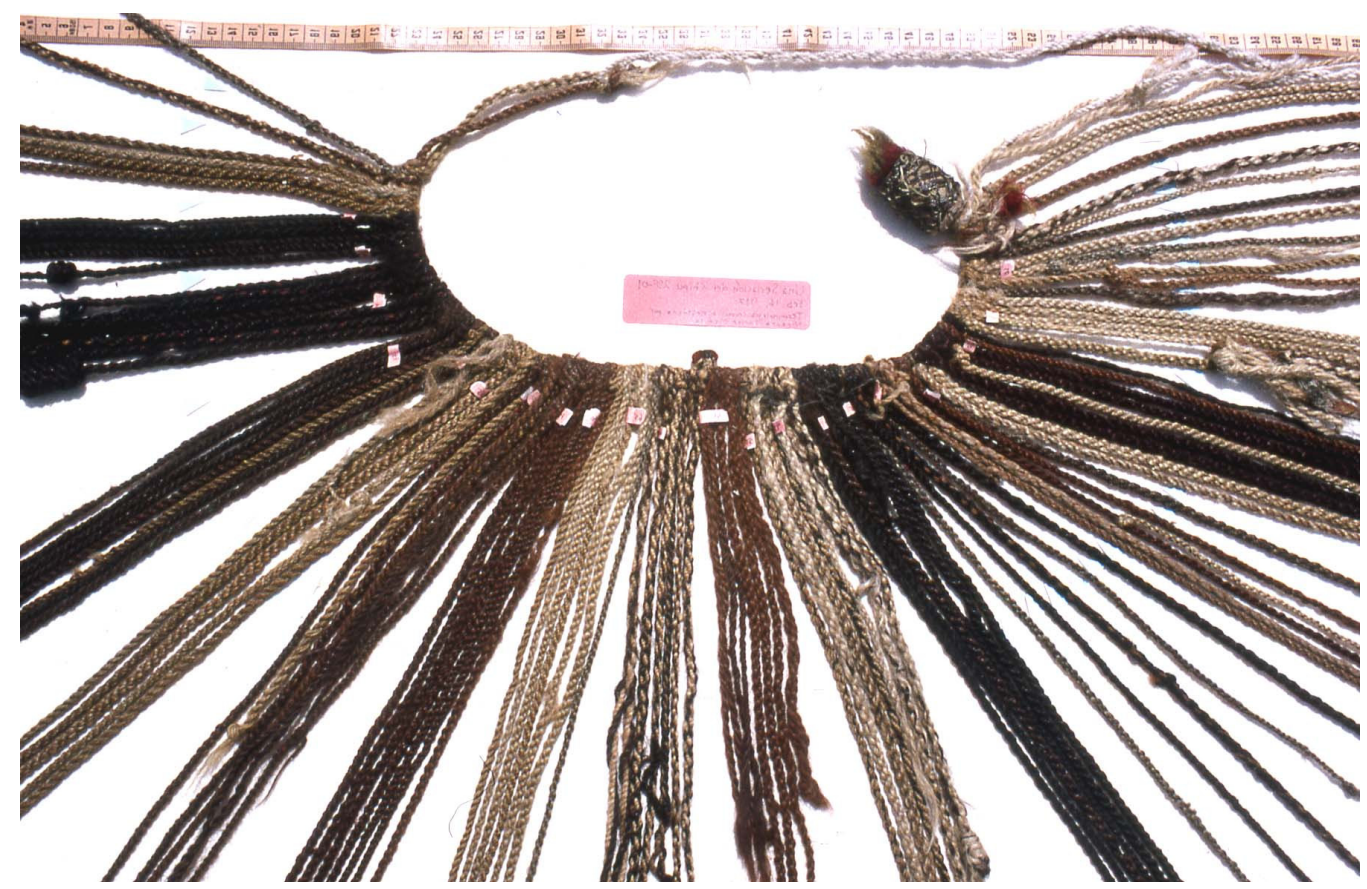

Figure 13: A khipu belonging to ayllu Segunda Satafasca of Tupicocha. The overall design matches canonical Inka design. Author's photograph.

moribund scripts. Made wholly or almost wholly of camelid wool, they bear richly ornamented end knobs and dorsal markers. They were obviously made to be treasured, and are spoken of as treasures: "They are our Magna Carta" is how one elder put it. The heterogeneous artifice of pendants suggests they are the work of many hands. Tupicochan khipus match in detail the khipus drawn by the "Indian chronicler" Felipe Guaman Poma de Ayala toward 1615.

Rapaz, another central-Peruvian high altitude village, owns the first set of patrimonial khipus ever to catch the eye of a researcher (Ruíz Estrada 1982). The khipu patrimony of Rapaz is the only known case where khipus endure in the original architectural complex of ritual, governance, and storage they were made to serve (Figures 14-15). Moreover, these buildings still house the ongoing work of traditional ceremony and production management, for whose sake khipus are held sacred. The collection consists of 263 discrete cord objects. It is not, as repeatedly misreported, a single "giant khipu" - except in the sense that the ensemble as a whole, with its separate parts, formed in local theory a single register.

The Rapaz patrimonial khipus could hardly be farther from Tupicochan khipus in material makeup (Salomon et al. 2006). Whereas Inka specimens have a single main cord from which multiple knot-bearing pendants are suspended, all the Rapaz khipus share a unilinear design in which all apparent signs are attached directly to a single, sometimes very long cord of camelid or (less often) sheep wool. Some exceed $15 \mathrm{~m}$, but it remains to be seen how much of the length is due to mending. The unilinear Rapaz design is more suggestive of seriated emblems (such as a Siouan winter count, that is, a chronicle composed of emblems for memorable events, or a Panamanian Kuna pictographic manuscript) than of data arrayed on the dual (horizontal / vertical) axes of Inka design. Rapaz emblems, unlike signs on blank hide or paper, rest upon a linear substrate that is complex in its own right. Both $\mathrm{S}$ and $\mathrm{Z}$ final plying of main cords are common. Main cords range very widely in design, from monochromes to eight-ply specimens with elaborate multiple plying. Almost all their colors are natural fiber hues, but in a few cases plies of 


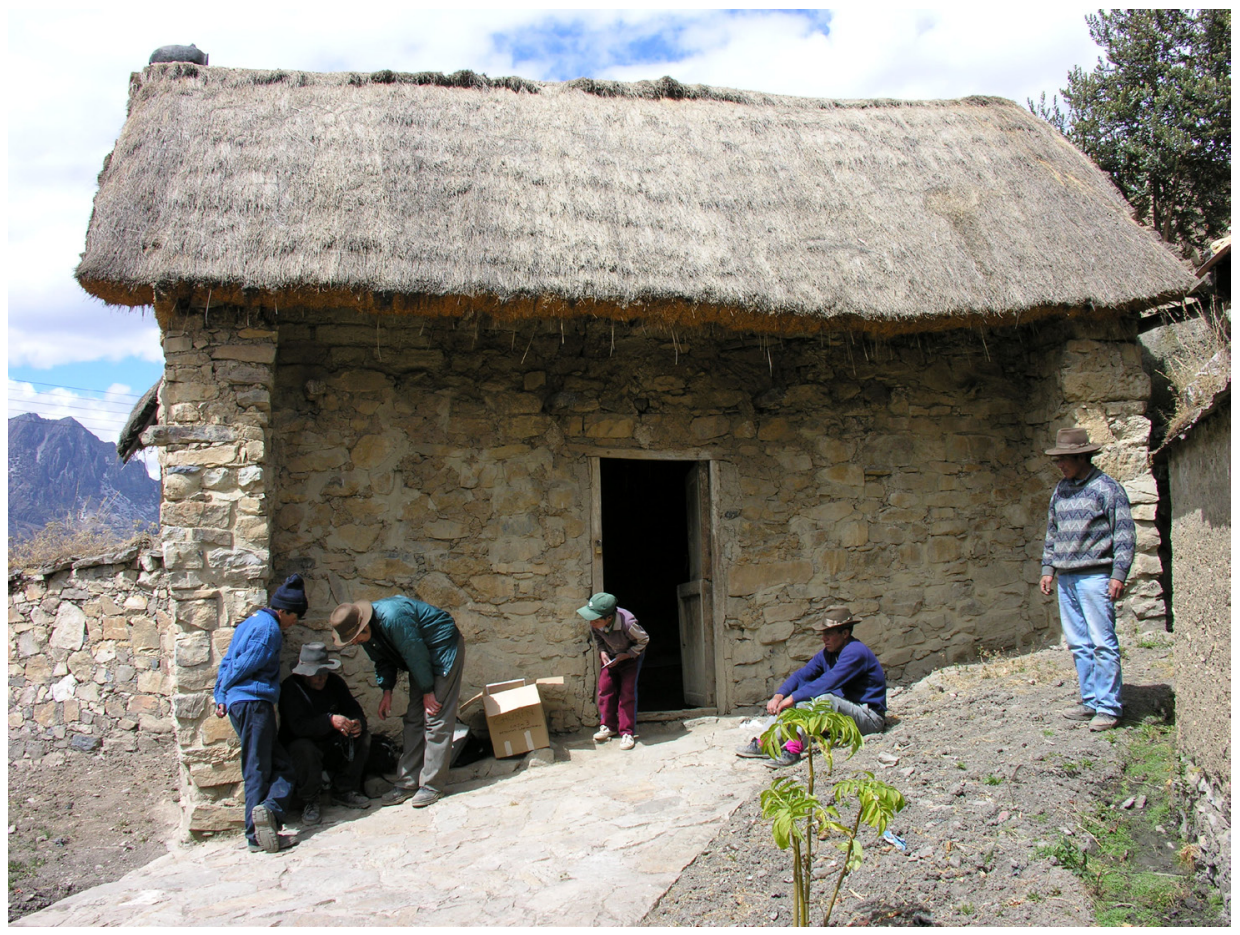

Figure 14: Kaha Wayi, the house of ritual and traditional governance in Rapaz. It houses a large collection of vernacular khipus. Author's photograph.

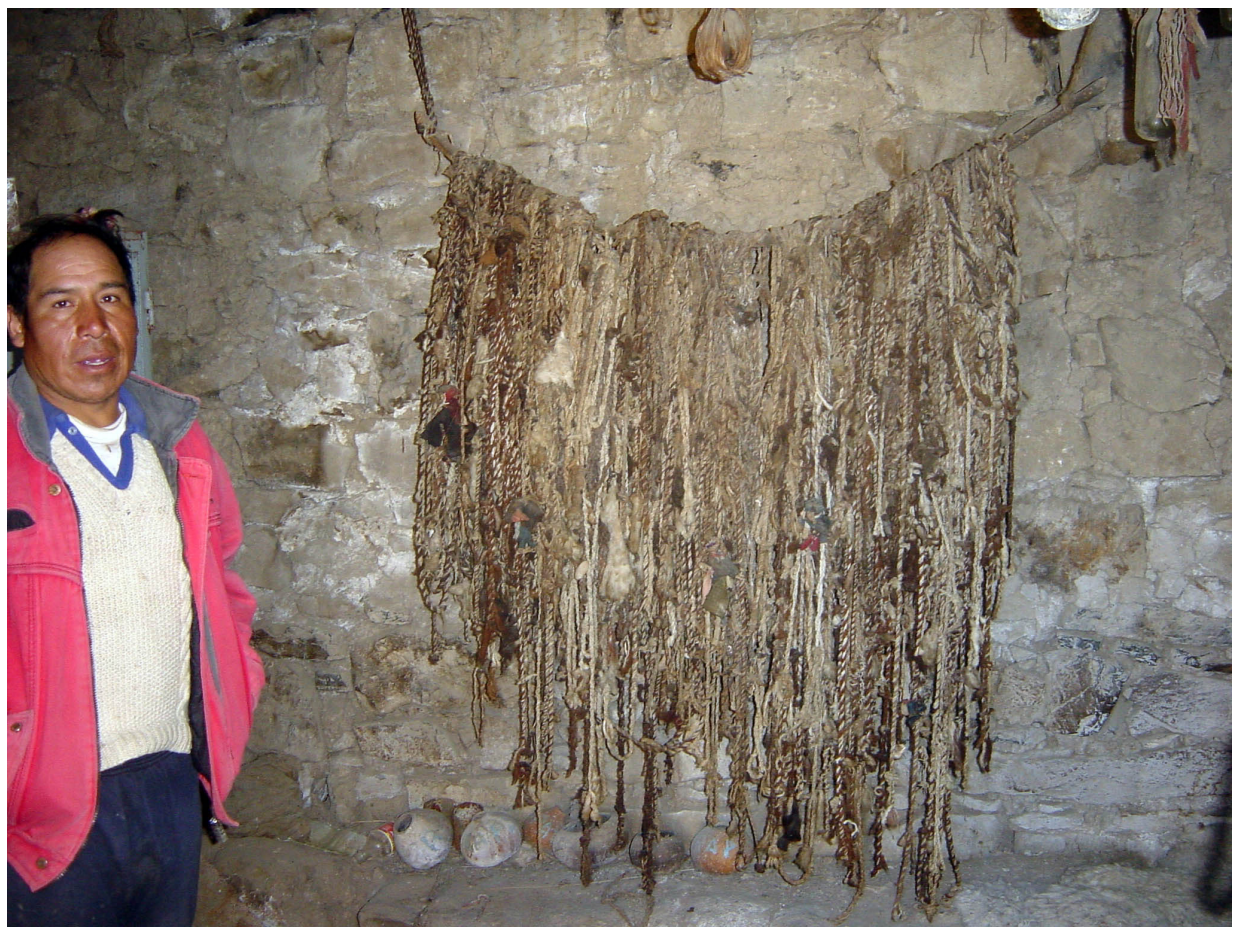

Figure 15: In 2004, Toribio Gallardo shows Rapaz’s khipu collection. Author’s photograph. 


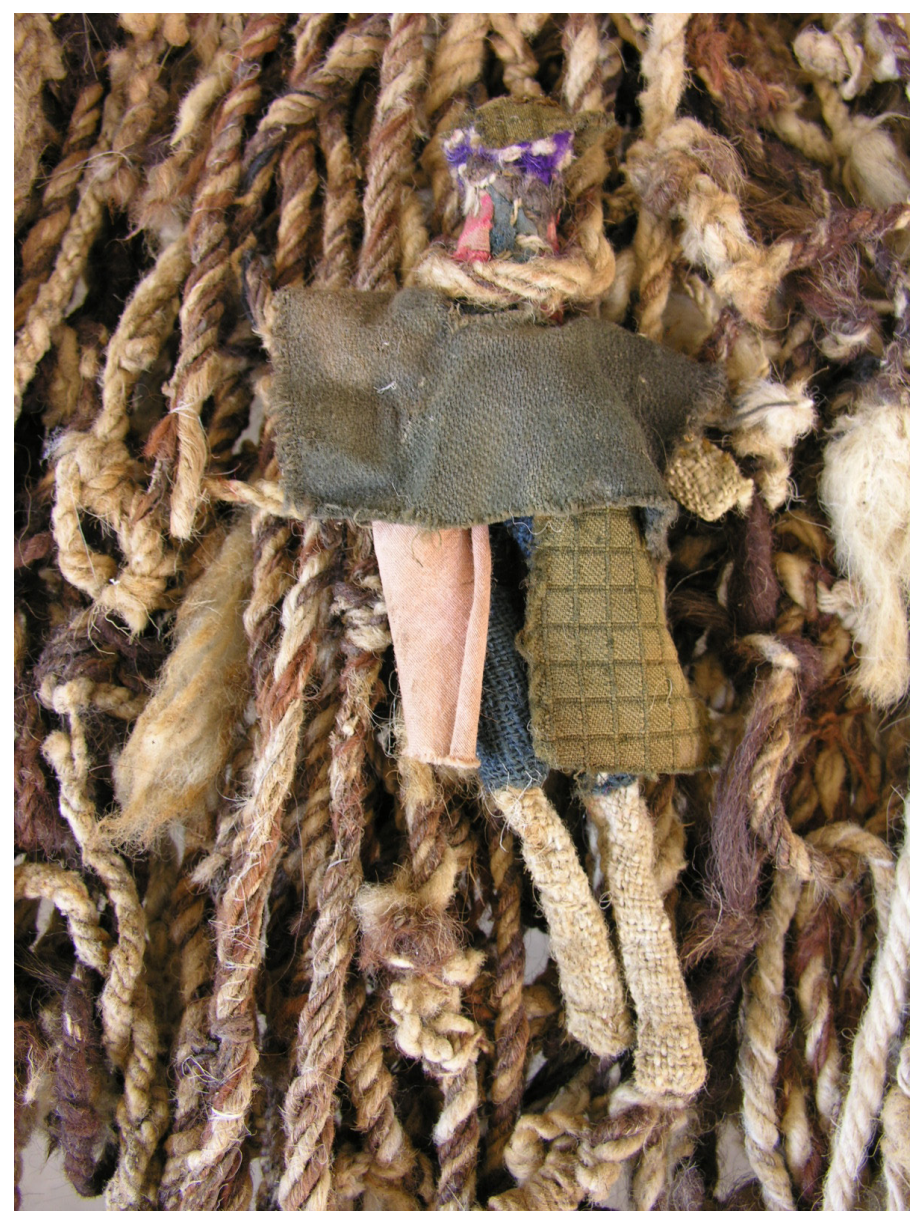

Figure 16: Some Rapaz khipus bear textile figurines. Author's photograph.

died wool extend through mostly-natural cords. Dye colors are greenish-blue or mustard yellow. The features attached to the main cord are not pendants in the Inka sense. Only one pendantlike structure in the whole collection is attached with the conventional Inka half-hitch. Rather, attached signs are typically knotted onto the main cord. Common attached signs can consist of either a short piece of tied-on cord, or a short tie-on holding some small object. Most such cords are knotted onto the whole main cord overhand, while some run between plies of the main cord. The objects they bear at their distal ends are tufts of wool in various natural colors, tags of rawhide, tags of hide with wool still on it, pompoms (frequently bicolored), and, in 10 cases, figurines (Figure 16).

One other patrimonial corpus has been described. Nelson Pimentel (2005), working in southwestern Bolivia, has written about what might be called patrimonial 'memory khipus'. Their originals have been lost. Elders who informed Pimentel replicated with modern yarn four khipus of apparently communal scope. These cords appear to have served as accounts of sacrifices (challay), genealogy, harvests and herds. In some of them, design at the coarsest level resembles the Inca canon. Smaller features may also be relevant to Inka traits: for example, one occasionally finds an Inka pendant tied around an adjacent similar one, a structure here explained as meaning that the former cord annuls the latter (Pimentel 2005: 29). Pimentel's cords also include structures and conventions potentially relevant to Inka format but not recognized in Urton's scheme: length 
of pendants, thickness of pendants, internodal distance, and minor but significant variations of shade within one color (e.g. violet for 'rebellion' as against purple for 'war', Pimentel 2005: 143). Salomon found related attributions of meaning to these academically unrecognized variables in Tupicocha. And finally, there are structures unknown in Inka khipus, such as cord interlacing (taken as a sign of actions in concert).

\section{The Functional Implications of Recording with Fiber}

Up to this point I have only supplied a factual base about the changing materiality of khipus. But were there material constants that affect the properties of the medium as a whole? And how consequential are they for expression and meaning? How did the specificity of cord influence ways to share meaning visually?

\section{Relatively Light Requirements for Tools and Special Inputs}

Inka testimonies claimed khipu as a monopoly of the imperial bureaucracy. But it is hard to see how the medium could have been monopolized, once one notices that all the materials and manufacturing skills - dyeing, spinning, knotting, ornamenting - are present in the routine of plebeian agropastoral households everywhere from southern Colombia to central Chile. Except for certain dyeing equipment, all the necessary gear was and is home-made and portable. Conklin (2002: 61) notes that one's own hands and toes suffice as a frame to make even complex cord. I have seen modern villagers make khipu-quality cords in minutes using no tools but the ubiquitous drop spindle.

Materially, then, khipu had a demotic potential. Moreover, Inka administration itself relied on widespread khipu competence available throughout rural society, and not on a restricted clique of experts. Martín de Murúa (1946 [1590]: 124) noted that local ethnic groups had their own khipu resources apart from Inka officialdom, and that officials depended on them for detailed records. From the 1560s through the 1590s trials often show local lords of non-Inka origin adducing khipu evidence as work of their own khipukamayuqkuna (khipu masters). Basic numerical khipu knowledge was widespread among campesino herders (male and female) up to approximately the 1960s. This demotic development underlay the medium's ability to convincingly represent Tupicocha as a totality to its own members: cords did not contain information reserved or manipulated by outsiders, but instead information transparent only to insiders.

\section{Movable Parts}

Against the grain of khipu literature, I argue that khipus functioned as operational devices or simulators, and not as fixed texts. The physical attributes of khipus, especially those in Inka or Inka-like format, suggest mobility and not fixity as the default (for other examples of physical adjustment cf. Piquette, this volume). Hernando Pizarro (1920 [1533]: 175) said that Inka accountants updated accounts by adding and removing knots. The first scholar to show that ancient khipus actually have changeable - and changed - parts was Carlos Radicati di Primeglio, in his book on "the Inka system of accounting" (1979(?): 97-102). He later summed this up:

A quipu with knots removed from its cords and re-knotted is, strictly speaking, a palimpsest, which can be reconstructed... It is amazing with what facility one can remake the knots, based on the traces which they leave marked on the cords. Unknotting is usually found on isolated cords, but sometimes also on a whole section. (Radicati di Primeglio 1990 [1987]: 91) 


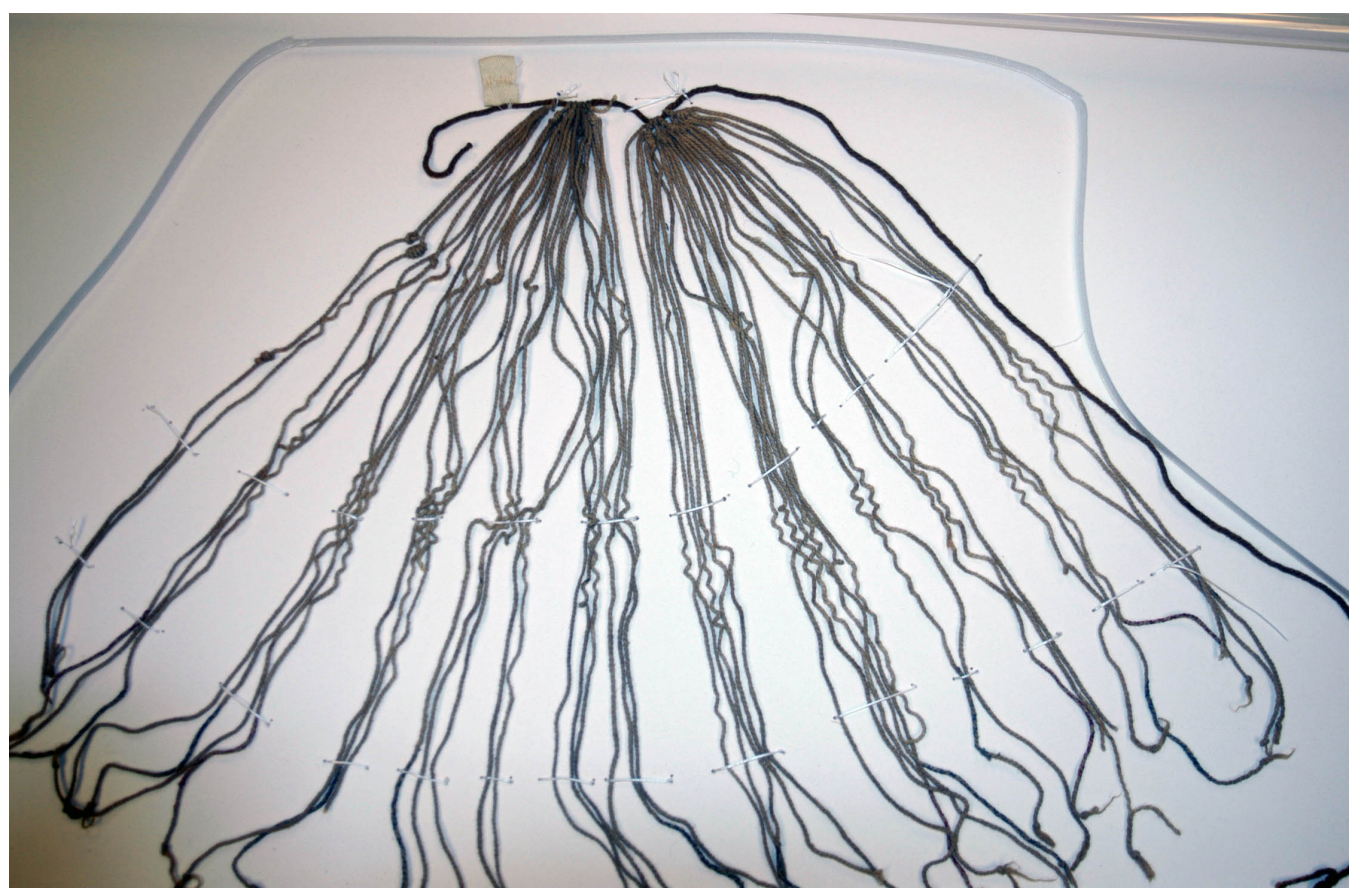

Figure 17: An Inka-era khipu with all its knots removed. Photograph courtesy of Gary Urton.

By "traces" Radicati was alluding chiefly to cuts, kinks and / or color discontinuities visible where a knot was removed. One known specimen has been completely un-knotted (Figure 17). When the "Indian chronicler" Felipe Guaman Poma de Ayala drew khipus, he drew all but one of them knotless.

And indeed many feature of the canonical khipu seem designed for ease in making alterations. If the default is operability - that is, if the working assumption of the makers was that khipus would change - then an operational khipu would have technical features allowing easy movement, removal, and attachment of elements. This is borne out in several ways. First, the standard attachment of pendants, the half-hitch, is the optimal one to allow either removing and reattaching a pendant individually, or repositioning it by sliding, without disturbing the rest of the structure. Some Tupicochan specimens show stretches of bare main cord while other specimens have jammed main cords. These seem to be carrying more pendants than they were designed for, so cords were likely added as time went by. Second, if a quipocamayo served as an operational device it is likely to show heterogeneity of manufacture. Tupicochan pendants in a single band do vary in texture, tightness, diameter and degree of wear. Third, if the hallmark of an operational device is movability of sign-bearing parts, those parts which are not to be moved, or to be moved jointly if at all, should bear signs or mechanical devices that impede mobility. Several such devices are in evidence, the firmest one being the binding of a group of pendants to each other with stitches right through their attachment loops.

\section{Lightness, Portability}

It has often been noticed that khipu are a portable medium par excellence. They weigh little, and can be easily compressed, flexed or rolled. They are not fragile. They are well suited to a society in which logistics over extreme mountain terrain was and remains a problem. The Inka state created 
a human Pony Express of relay runners (chaski) who carried khipus; Guaman Poma (Figure 18) drew a chaski of the Inka post tearing past with a khipu labeled "letter" in his hand. The Inka empire, with its intricately standardized systems of intervention and control over local polities, can hardly be imagined without the means to move large bodies of data in standard formats over distances. It would be no exaggeration to call coding of information on textile fiber a core infrastructure of Andean social organization.

\section{Flexibility Yielding Variable Physical State}

Flexibility is also a central property, affecting storage, reference and display.

\section{The Coiled Storage State}

From Inka times to the present (Figure 19) khipus have been stored in a spiral position: the users extend the main cord horizontally with pendants hanging free, then wind it from the knob-end to the tail end, so that the main cord forms a spiral cone with knob-end protruding. The dangling tail end then serves to bind the pendants into a flexible, cylindrical fascicle which can be bundled with minimum tangling.

Flexible-storage design served to ease retrieval. The end knob probably identified khipus. In the surviving Tupicocha suite, each ayllu had paired display khipus with elaborate, distinctive knobs resembling their respective mates. Some Inka khipu also have end knobs (Figure 20). Having found the right khipu in storage state, a khipu user would then study the spiral-cone storage view of the main cord, using it as a table of contents, before unwinding it. Since pendants are usually clustered and color-coded, it would be easy to find the relevant cluster and string. Since khipu pendants can number over a thousand, this would be a non-trivial advantage. 'Markers' (usually colorful tufts) lashed onto main cords also served as 'bookmarks' pointing out important loci.

\section{The Overknotted Display State}

In Tupicocha, khipus are moved from storage to the annual 'town meeting' or huayrona in a special arrangement used at no other time. The coiled storage setup is lifted from either end, and twisted so that the whole fascicle of pendants is changed into one thick cable $(10 \mathrm{~cm}$ or more in diameter). The handlers then wrestle the cabled khipu into a single immense knot (Figure 21). The owning ayllu parades it in state, displayed on a cushion, en route to the meeting. It acts as a visual image symbolizing all the data (knot) which will be resolved (unknotted) at the assembly. At the end of the meeting, the khipu is not re-cabled but rather carried to its home unbound, signaling the resolution of data. This practice is unknown in archaeological evidence. It appears to be a colonial or postcolonial practice derived from the inherent physical potentials of the medium.

\section{The Suspended 'Reading' State}

Surviving colonial images of khipus in use, like the numerous lawsuits registering work of khipu accountants, sometimes indicate that consultation of khipus was done by at least two people jointly as holder(s) and reader(s). An immense specimen from Mollepampa, Chile, required two people just to suspend it (Museo Chileno de Arte Precolombino 2003: 20). In Tupicocha, upon unwinding, the pendants are 'combed' by finger for clear positioning. To judge by the use of fingers in de Murúa's 1590 rendering (Figure 22) this might be an ancient practice. 


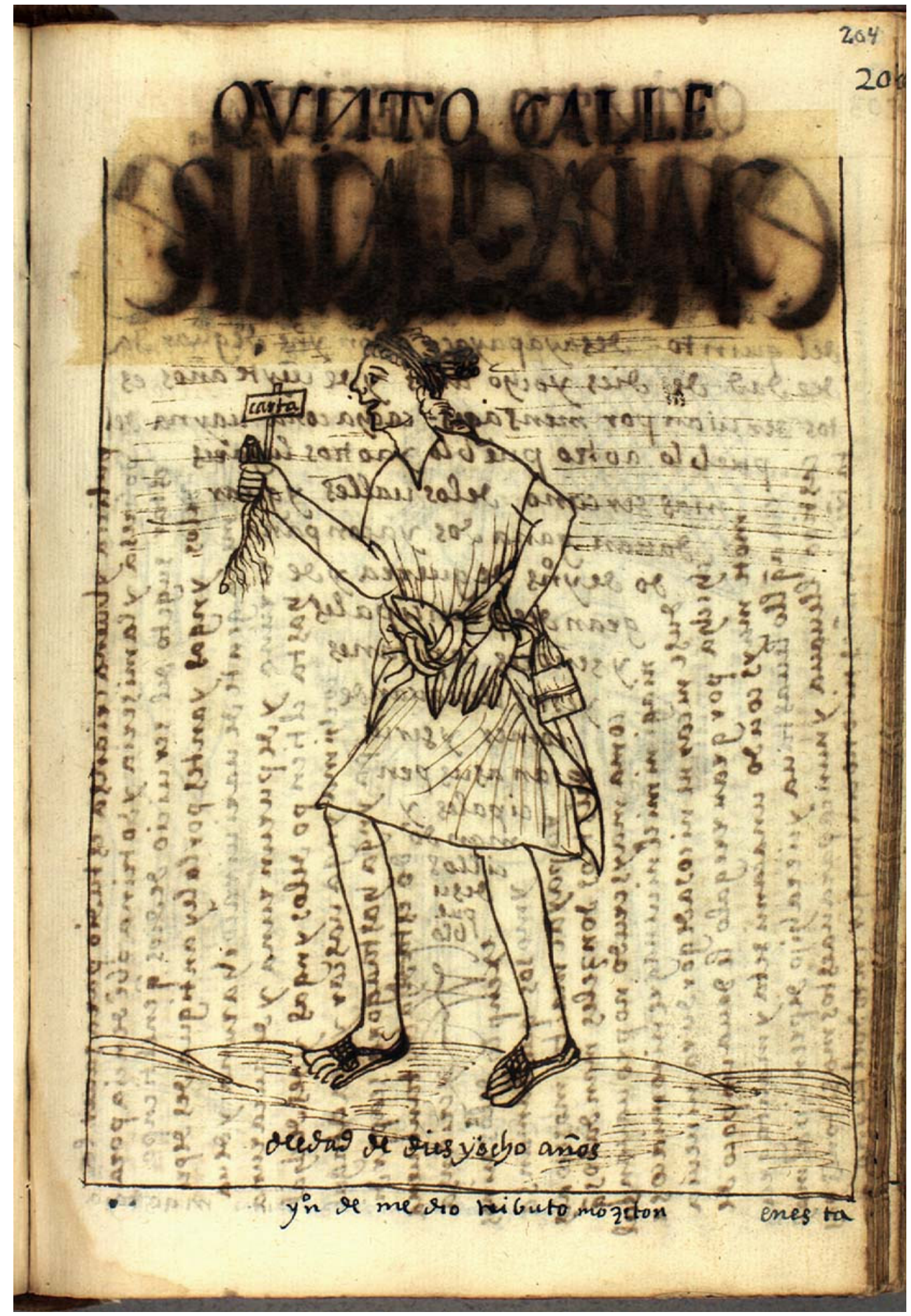

Figure 18: Felipe Guaman Poma de Ayala drew this Inka postal runner with a khipu labeled "letter" (1980 [1615]: 178). 


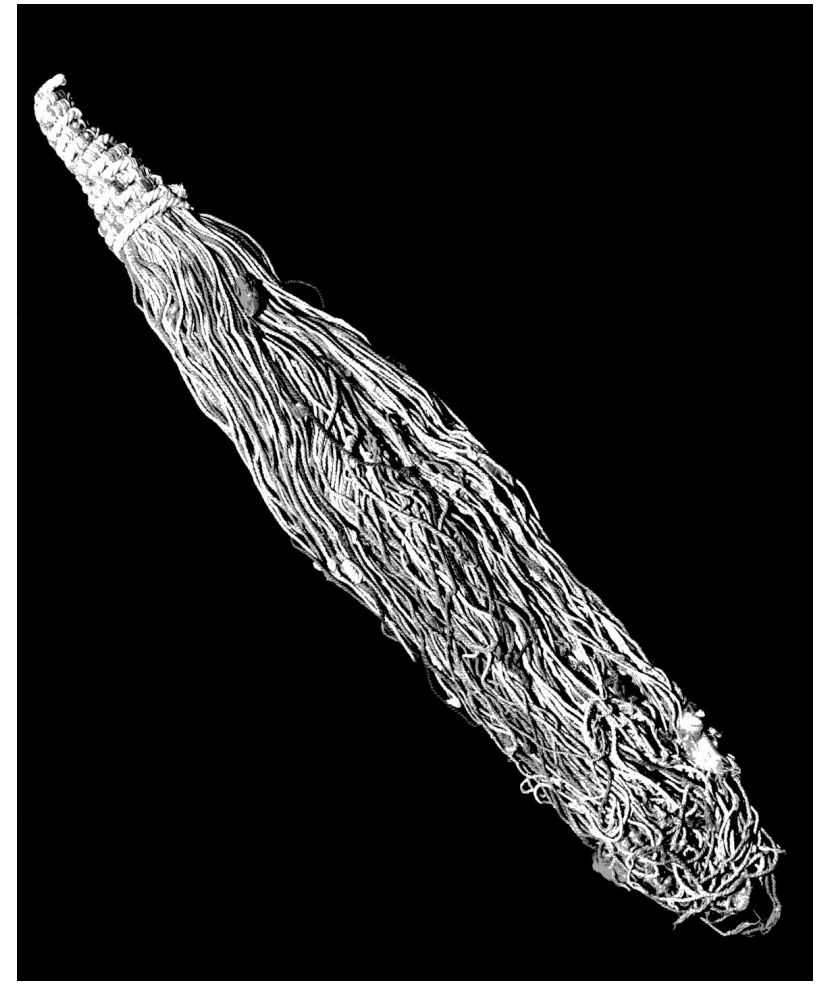

Figure 19: Inka khipu bound in fascicle for storage. Photograph courtesy of William Conklin.

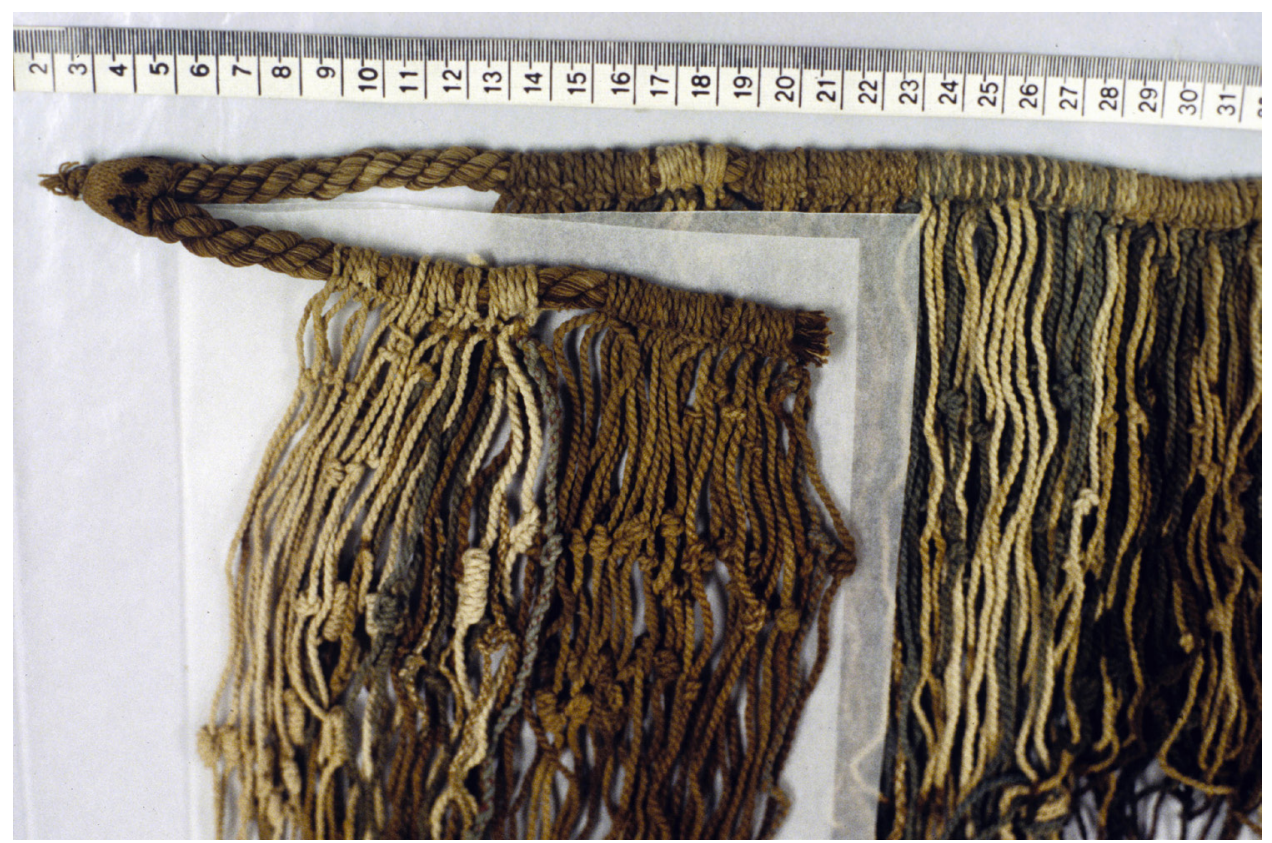

Figure 20: Khipu(s) 41-2-6993 of the American Museum of Natural History are apparently marked as a pair by common attachment to a single end knob. Author's photograph. 




Figure 21: The Tupicochan practice of twisting an entire khipu into a single huge knot. Author's photograph.

A very few archaeological khipus have wooden frames which, instead of coiling, serve to hold the pendants in constant 'open' array for 'reading'. One example (Ascher and Ascher 1997: 97-101) consists of a pair of framed khipus with matching mathematical frameworks (Tupicochan khipus were also paired). The array is quite complex. By threading the main cord in and out of holes in the frame, the makers created "subcharts...physically back-to-back". Perhaps this technique was suited for benchmark or summary khipus requiring frequent reference, comparable to a bookstand for bound texts that need to lie open.

\section{The Draped Ceremonial State}

In Tupicocha, but not in archaeological contexts, the khipu is draped upon the body of the person who will incarnate its authority during the coming year. This, too, is a four-handed job. The outgoing ayllu president lifts it and drapes it from the right shoulder to the left hip of the incoming president, then ties it "like a presidential sash" (as in Figure 12). This act climaxes and dissolves the 'town meeting', marking the moment when all past business is considered resolved and a new political cycle initiated. Although it is wordless act, draping is considered an embodied oath of office.

Draping appears to be another emergent colonial or postcolonial practice derived from the inherent physical potentials of the medium. All these khipu states functioned between at least two persons. Tupicochans were surprised by my attempts at solitary khipu use, as I spread khipus out horizontally on a table. They considered it indecorous to prostrate the khipu flat and to use it without social support. All signs point toward the conclusion that khipu use was considered an inherently cooperative activity. 




Figure 22: The 1590 de Murúa manuscript illustrates cooperative reading and finger-sorting of cords (de Murúa 2004: 124 verso).

\section{Expandability Through Nested and Conjoinable Design}

From something hanging, one can hang something else. To something tied, one can tie something else. Khipu design uses these two physical facts to enable (in principle) the indefinite formal extension and proliferation of any given data frame. To put the same thing another way, canonical Inka khipu design and some vernacular versions are recursive, like the syntax of natural languages: into a relative clause one may insert another relative clause, etc.

\section{Nestedness}

With few exceptions (markers and other metasigns) any given cord structure may be part of a larger cord structure of the same design, or may conversely bear subordinate members of like 


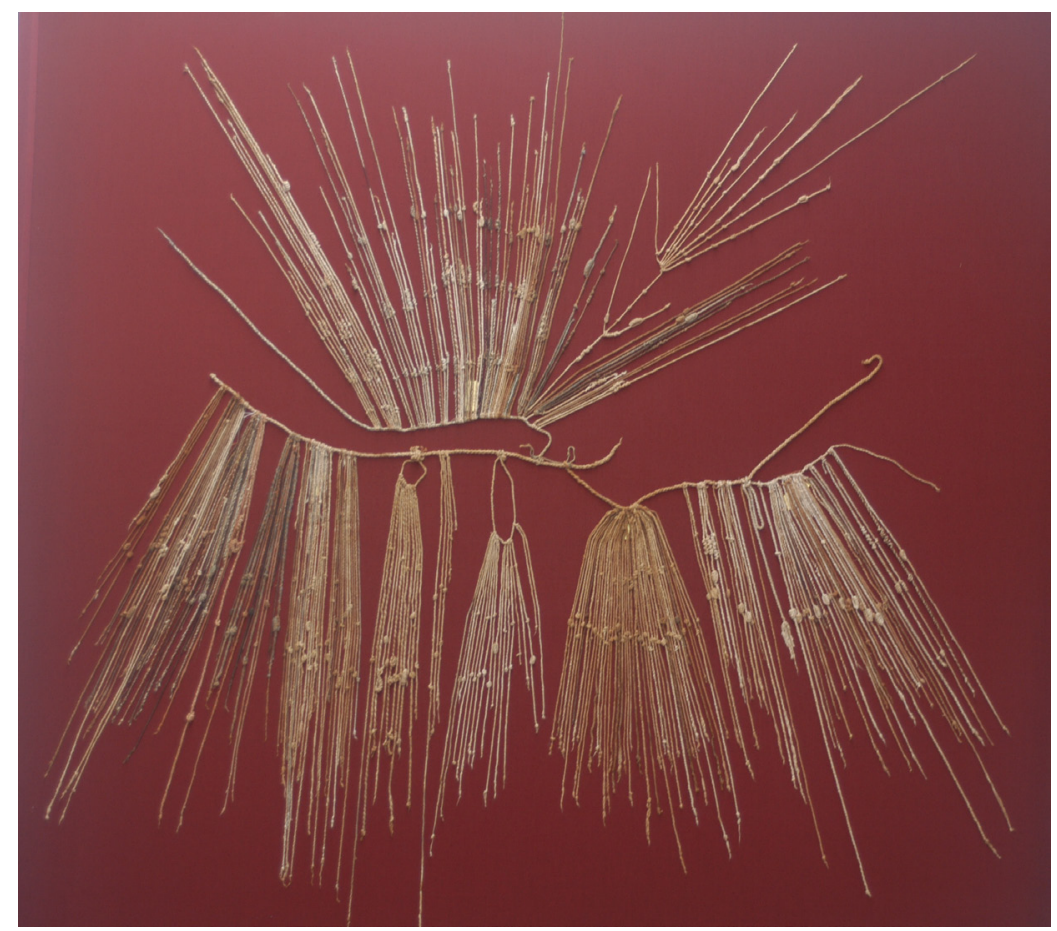

Figure 23: At Laguna de los Cóndores, some Inka-era khipus found with enshrined mummies were tied to each other. Photograph courtesy of Gary Urton.

design. A pendant bears subsidiaries but subsidiaries bear sub-subsidiaries. Subsidiary structures up to 12 levels deep have been found. Even a whole khipu, i.e. main cord plus pendants, may be a part of a larger khipu. Conklin observed that already in Middle Horizon khipus, "string groups... are virtually little quipus in themselves, containing up to three more hierarchies of dependency" (Conklin 1982: 277). Urton found more pervasive examples of this principle in the khipus from Laguna de los Cóndores. Two examples are visible in the lower left part of Figure 23. He calls the small sub-khipus slung from the main cord 'loop pendants' (Urton 2007: 25). One main cord held 24 loop pendants, each related to a corresponding but separate first-order pendant.

Nestedness pervades fiber structures. Nestedness greatly interested Inka designers, even to the point of designing tunics whose surface consisted of emblems (tukapu) of other whole tunics. Nested structures are congenially congruent to many hierarchies in which small structures combine to make large ones of the same form: for example, ayllus, or decimal brackets in Inka administration.

\section{Conjointness}

There is another way for a khipu to form a part of a larger khipu: instead of nesting, main cords are attached directly to each other (Figure 23). In practice it is hard to tell which junctures imply horizontal combination of two corpora, and which ones imply hierarchical subordination, but horizontal combinations certainly exist. In one case, they are joined to make a ring of main cords (Figure 24). Conjointness is congruent to relations among peer units, like allied polities, neighboring villages, or sibling-ayllus. It is important to notice that such relations do not necessarily imply equality or interchangeability, because peer segments are often seriated; in Andean ritual they stand in relations of ritual precedence, which imply rank among fellows. 


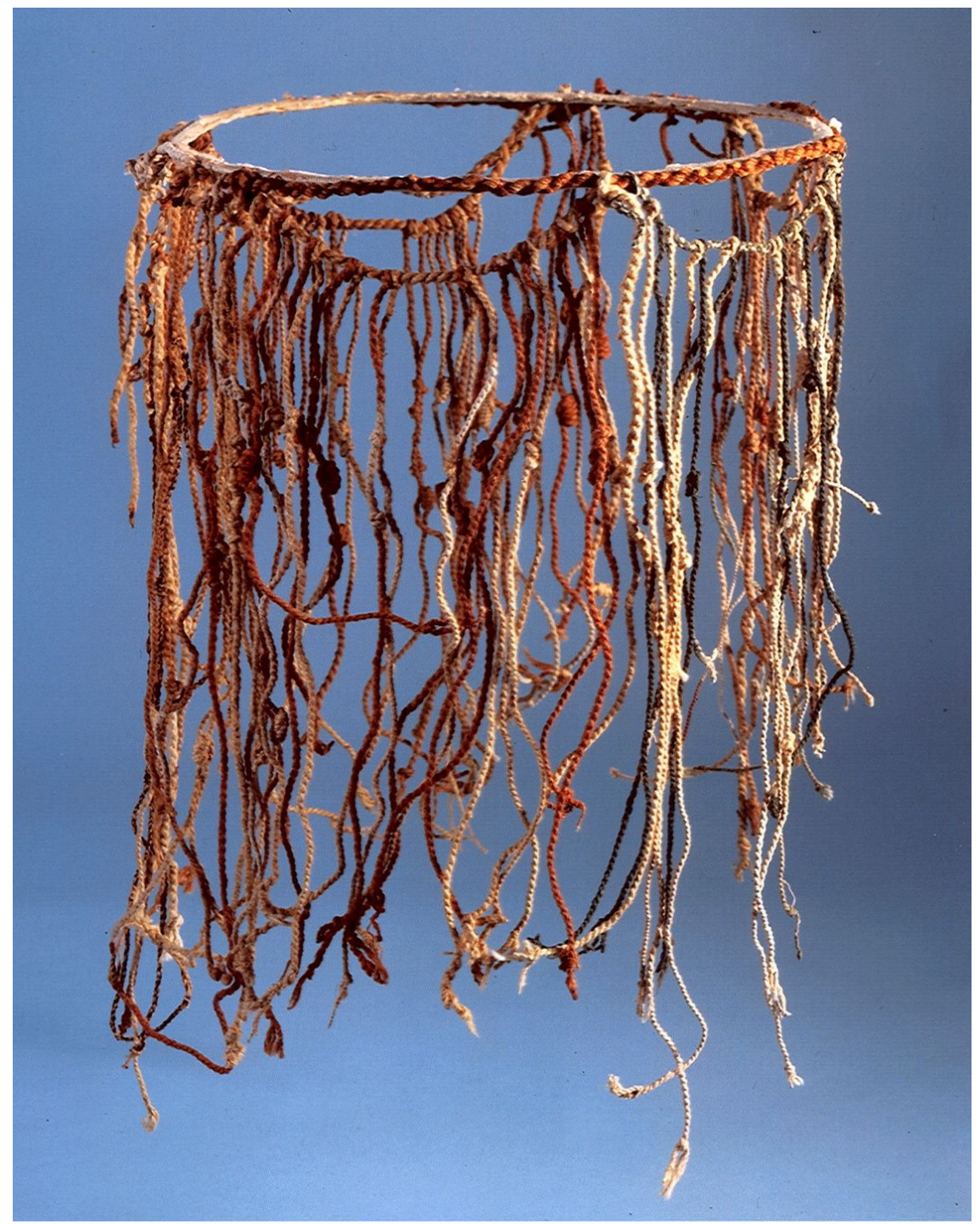

Figure 24: The Peabody Museum at Harvard holds a ring-shaped set of five conjoined khipus. Photograph courtesy of the Peabody Museum.

Urton has studied numerical and categorical relations among khipus of less and more aggregated nature within a single Inka-era khipu archive, developing from the phenomenon of nesting a model of khipu 'intertextuality'. Numerical patterns in lower-level detailed khipus were extracted and summarized in more aggregated high-level ones. This practice in effect extends the phenomena of nestedness and conjointness upward and outward, regardless of whether the parts are physically tied together.

\section{Articulation with Auxiliary Media}

Formal relations within khipu could readily be transcribed into other secondary media to speed up manipulation. Transcripts of colonial trials involving khipus mention that khipu testimony 
was not necessarily rendered directly from cords to verbal forms, but often through an auxiliary medium, of which the usual one was small stones arranged and manipulated on the ground. Apparently this procedure enabled experts to answer by reorganizing and perhaps recalculating partial khipu contents, as one might do today with a spreadsheet, schedule chart, or wiring diagram. Manipulation through an accessory medium could be a complex enough process to require a court recess (de la Puente and Curátola 2008). We also know that Andean peoples possessed abacus-like aids in the form of counting-boards called yupana which held counting tokens in ordered cells (Wassén 1990 [1931]).

\section{Inclusions and 'Semiotic Heterogeneity'}

Tying one thing onto another does not necessarily imply tying on more of the same kind of thing (as in the nested structures discussed above). Khipu makers also sometimes tied on non-cord items such as tufts of wool, small sticks, rawhide tags, or even figurines. These might seem extraneous to cord media as such. But Galen Brokaw points out that mixing signs from several codes with separable reference systems is normal in many scripts: "Most complex media have a certain degree of semiotic heterogeneity. Alphabetic script is based on the principle of phonemic representation, but it also incorporates non-phonemic conventions such as Arabic numerals, punctuation marks, and spaces between words" (Brokaw 2010: 21). Extending the alphabetic example, one could point out that the mixed codes in heterogeneous sign-sets not only refer to different things (speech sounds, speech rhythms and intonations, and quantities) but also refer in different ways (letters being phonographic, numerals semasiographic and word spaces iconic). On khipus, sticks taken as likenesses of animals introduce iconic reference, while wool itself may be an indexical one.

Normal as 'semiotic heterogeneity' is, cord physicality seems a particularly open invitation to it, since cord is par excellence the means of binding varied objects together. This kind of heterogeneity seems most typical of post-Inka khipus. It reaches an extreme in Rapaz's seriated-emblem khipus.

\section{Linearity}

Whatever else cords may be, they are linear right down to their atomic level (raw fiber). Tim Ingold could have made them a key case in his book Lines, on the way cultures construe linearity (Ingold 2007).

Khipu students have long wondered whether cord lines might not have served iconically to represent paths in spatial relationships. It is an Andeanist commonplace to comment that the ceque pattern of ritual lines radiating out from the Inka sacred city of Cuzco, with shrines forming nodes along them, looks like a giant khipu laid onto the landscape.

Inca-linked informants often said cords supported narratives: dynastic history and genealogy, laws, chansons de geste and ritual protocols. The Aschers (1982: 75) pointed out that a narrative, considered as a sequence of stylized or generic speech events (strophe, episode, etc.) could be matched to the linear, segmented, discrete format of khipu. A cord series knotted with indicators of certain types of events and values for them would suffice to structure, for example, a dynastic chronicle - though not the necessarily phonological representation of specific words in it. Catherine Julien (2000: 11-13, 226-228) and Brokaw (2003) argue that Inka dynastic histories rendered from, or written by, Andean experts bear specific formal structures carried over from khipus. Far from the Andean orbit, Wassmann (1991 [1982]) provides a detailed ethnography of how a Sepik River group in Papua-New Guinea practices an elaborate sequence of ritual oratory based on a cord device.

Abercrombie (1998) has gone the farthest in asking us to see khipu cords as predominantly 'pathways'. He regards cords as iconic maps or guides representing passages through space and 
/ or time ('chronotopographs'), or even trains of thought moving through a purely mental space such as hierarchy.

\section{Three-Dimensionality}

It has been noted (Cummins 1994) that, in part and in whole, khipus inherently are solids rather than pure lines. This allows tactile legibility, at least theoretically. One colonial source asserts that a blind man made and read an immense khipu as an aid to Catholic confession (Harrison 2002: 281). Experienced spinners can indeed recognize many structures by touch, but the central importance of color makes the idea of tactile legibility less plausible.

\section{Concluding Suggestions}

Physical properties of khipus do not by themselves bear centrally on the question of whether khipu could have encoded linguistic sound-segments and thereby entered the sacred circle of 'true writings'. Khipu materiality does, however, suggest that the medium was exceptionally strong in representing relations other than linguistic ones. The technology has an inherent bent toward emphasizing discrete category, hierarchy, number and grouping. One cannot create a canonical khipu without implications about some of these. It also seems to have been inherently strong for usage as an operational simulating device. Khipu would be as good for representing ongoing updates or rearrangements of information as it is for permanent fixation.

Khipus' physicality compels us to pay special attention to category and number, the same variables Damerow (1999) identified as the core of meaning in Proto-Cuneiform. A canonical khipu has some resemblance to the rationing tables, rich in both semasiograms and numerals, which Damerow deciphered. However the term 'proto' misleads one into thinking that inscription built up from noun-number inscription has an inherently low functional horizon. Perhaps the khipu art represented 'proto' inscription carried onward toward elaborateness in its own terms, rather than redirected to phonographic representation via the rebus mutation. One way to combine the now well-developed mathematical study of khipus with newer findings about color, mirrorsymmetry variations, and hierarchical structure would be to think of khipus as a script which is inherently a diagram.

The philosopher Nelson Goodman, in studying the properties of different semiotic toolkits, invented a special usage of the word model which seems to capture very well the peculiar relation between matter and meaning in khipus. "Models...in effect diagrams...in more than two dimensions, and with working parts; or in other words, diagrams are flat and static models. Like other diagrams, models may be digital or analog or mixed" (Goodman 1976 [1968]: 172-173). One can think of Andean societies, especially but not only Inka-era ones, as engaged in constructing themselves by storing, updating, and exchanging visual models rather than verbal transcriptions. Whether or not that is 'writing' does not need to be fought about immediately. What does matter is learning to recognize "graphical excellence" (Tufte 1983: 182) in its less familiar forms.

\section{Note}

${ }^{1}$ Another khipu - alphabetic interface seems to have been invented on the ecclesiastical side: the hybrid khipu - alphabetic objects known as 'khipu boards'. Two drawings which may show khipu boards in the catechesis of women come from the remote north coast c.1789 (Martínez Compañón 1985 [c. 1779-1789]: 53-54). In 1852 the scientific traveler Mariano Rivero observed that "in some parishes of Indians, the khipu were attached to a panel with a register of 
the inhabitants on which were noted "their absences on the days when Christian doctrine is taught” (Sempat Assadourian 2002: 136). Toward 1923, Julio C. Tello and Próspero Miranda observed one in use at Casta, near the northern edge of Huarochirí Province. Its function was to govern participation in the village's canal-cleaning collective labor days and associated rites honoring the divine owners of water. As late as 1968 another specimen of $19^{\text {th }}$-century origin was discovered, in disuse, at the church of Mangas in central Peru (Robles Mendoza 1990 [1982]: 9).

\section{References}

Abercrombie, T. A. 1998. Pathways of Memory and Power: Ethnography and history among an Andean people. Madison: University of Wisconsin Press.

Ascher, M. and Ascher, R. 1997 [1981]. Code of the Quipu: A study of media, mathematics, and culture. New York: Dover Publications.

Betanzos, J. de 1987 [1551]. Suma y narración de los incas (edited by María del Carmen Martín Rubio). Madrid: Atlas.

Brokaw, G. 2003. The Poetics of Khipu Historiography. Latin American Research Review 38(3): 111-147. DOI: http://dx.doi.org/10.1353/lar.2003.0029

Brokaw, G. 2010. A History of the Khipu. New York: Cambridge University Press.

Burns, K. 2004. Making Indigenous Archives: The Quilcay Camayoc of colonial Cuzco. Paper given at conference "Archives and Empires", University of Notre Dame, April 3-5, 2004.

Cabello Valboa, M. 1951 [1586]. Miscelánea antártica. Lima: Universidad Nacional Mayor de San Marcos.

Cherkinsky, A. and Urton, G. forthcoming. Radiocarbon Chronology of Andean khipus. Open Journal of Archaeometry.

Conklin, W. J. 1982. The Information System of the Middle Horizon Quipus. Annals of the New York Academy of Sciences 385: 261-281. DOI: http://dx.doi.org/10.1111/j.1749-6632.1982. tb34269.x

Conklin, W. J. 2002. A Khipu Information String Theory. In Quilter, J. and Urton, G. (eds), Narrative Threads: Accounting and recounting in Andean khipu. Austin, TX: University of Texas Press, 53-86.

Conklin, W. J. and Splitstoser, J. 2009. Andean Stick Wrapping: A review of its 2000 year history. Paper given at the 2007 Annual Meeting of the Institute of Andean Studies, Berkeley.

Cummins, T. 1994. Representation in the Sixteenth Century and the Colonial Image. In Boone, E., and Mignolo, W. (eds), Writing Without Words. Durham, NC: Duke University Press, 188-219.

Damerow, P. 1999. The Origins of Writing as a Problem of Historical Epistemology. Berlin: Max Planck-Institut für Wissenschaftsgeschichte. Preprint 114.

de la Puente Luna, J. C. and Curátola, M. 2008. Nudos, piedras, y maíz: Los quipus coloniales de la provincia de Lucanas (1581). Paper given at VII Congreso Internacional de Etnohistoria, Lima, 5 August 2008.

de Murúa, M. 2004 [1590(?)]. Códice Murúa: historia y genealogía de los reyes incas del Perú del padre mercenario Fray Martín de Murúa: códice Galvin. Madrid: Testimonio Compañía Editorial.

de Murúa, M. 1946 [1590]. Historia del origen y genealogía real de los reyes Incas del Perú. Madrid: Biblioteca Missionalia Hispánica, Instituto Santo Toribio de Mogrovejo, y Consejo Superior de Investigaciones Científicas.

Guaman Poma de Ayala, F. 1980 [1615]. Nueva corónica y buen gobierno del Perú (edited by John V. Murra and Rolena Adorno, with translations by Jorge L. Urioste). 3 volumes. México DF: Siglo XXI. 
Goodman, N. 1976 [1968]. Languages of Art: An approach to a theory of symbols (2 ${ }^{\text {nd }}$ edition). Indianapolis: Hackett Publishing.

Harrison, R. 2002. Pérez Bocanegra’s Ritual Formulario. In Quilter, J. and Urton, G. (eds), Narrative Threads: Accounting and recounting in Andean khipu. Austin, TX: University of Texas Press, 260-290.

Herrmann, B. and Meyer, R. 1993. Südamerikanische Mumien aus vorspanischer Zeit: Eine radiologische Untersuchung. Berlin: Staatliche Museen zu Berlin-Preussischer Kulturbesitz.

Holm, O. 1968. Quipu o sapan: un recurso mnemónico en el campo ecuatoriano. Cuadernos de Historia y Arqueología (Guayaquil) 18:(34/35): 85-90.

Ingold, T. 2007. Lines: A Brief History. London and New York: Routledge.

Julien, C. 2000. Reading Inca History. Iowa City: University of Iowa Press.

Locke, L. 1923. The Ancient Quipu, or Peruvian Knot Record. New York: American Museum of Natural History.

Locke, L. 1928. Supplementary Notes on the Quipus in the American Museum of Natural History. (Anthropological Papers of the American Museum of Natural History 30). New York: American Museum of Natural History, 30-73.

Loza, C. B. 1998. Du bon usage des quipus face à l'administration coloniale espagnole (15001600). Population 1-2: 139-159. DOI: http://dx.doi.org/10.2307/1534240

Mackey, C. 2002. The Continuing Khipu Tradition: Principle and practice. In Quilter, J. and Urton, G. (eds), Narrative Threads: Accounting and recounting in Andean khipu. Austin, TX: University of Texas Press, 320-348.

Mann, C. 2005. Unraveling Khipu's Secrets. Science 309(5737): 1008-1009.

Martínez Compañón, B. J. 1985 [c.1779-1789]. Trujillo del Perú, Volume 2. Madrid: Instituto de Cooperación Iberoamericana.

Museo Chileno de Arte Precolombino 2003. Quipu: Contar anudando en el impoerio inka. Santiago: Museo Chileno de Arte Precolombino and Harvard University.

Núñez-Carvallo, S. 2008. Cabello Valboa, Miguel (c.1530-1606). In Pillsbury, J. (ed.), Guide to Documentary Sources for Andean Studies, Volume 2. Norman: University of Oklahoma Press, 91-94.

Nuñez del Prado, O. 1990 [1950]. El kipu moderno. In Mackey, C., Pereyra, H., Radicati, C., Rodríguez, H. and Valverde, O. (eds), Quipu y yupana: Colección de escritos. Lima: CONCYTEC, 165-182.

Pärssinen, M. and Kiviharju, J. (eds) 2004. Textos andinos: Tomo I: Corpus de textos (Serie Hispano-Americano 6). Madrid: Instituto Iberoamericano de Finlandia.

Pereyra, H. 1997. Los quipus con cuerdas entorchadas. In Varón Gabai, R. and Flores Espinoza, J. (eds), Arqueología, antropología e historia en los Andes: Homenaje a María Rostworowski. Lima: Instituto de Estudios Peruanos, 187-198.

Pimentel, H. N. 2005. Amarrando colores: La producción del sentido en khipus aymaras. La Paz: CEPA, Latinas Editores.

Pizarro, H. 1920 [1533]. A los Señores Oydores de la Audiencia Real de Su Magestad. In Urteaga, H. H. (ed.), Informaciones sobre el antiguo Perú: Colección de Libros y Documentos Referentes a la Historia del Perú, Volume 3 ( $2^{\text {nd }}$ series). Lima: Sanmartí, 16-180.

Prochaska, R. 1983. Ethnography and Enculturation of Weaving on Taquile Island, Peru. Unpublished MA dissertation, University of California at Los Angeles.

Radicati di Primeglio, C. 1979(?). El sistema contable de los Incas: yupana y quipu. Lima: Libreria Studium.

Radicati di Primeglio, C. 1990 [1987]. Hacia una tipificación de los quipus. In Mackey, C., Pereyra, H., Radicati, C., Rodríguez, H. and Valverde, O. (eds), Quipu y yupana: Colección de escritos. Lima: CONCYTEC, 89-95. 
Rama, A. 1996 [1984]. The Lettered City (translated by John Charles Chasteen). Durham, NC: Duke University Press.

Robles Mendoza, R. 1990 [1982]. El kipu alfabético de Mangas. In Mackey, C., Pereyra, H., Radicati, C., Rodríguez, H. and Valverde, O. (eds), Quipu y yupana: Colleción de escritos. Lima: CONCYTEC, 195-202.

Ruíz Estrada, A. 1982. Los quipus de Rapaz. Huacho, Peru: Centro de Investigación de Ciencia y Tecnología de Huacho.

Salomon, F. 2004. The Cord Keepers: Khipu and cultural life in a Peruvian village. Durham, NC: Duke University Press. DOI: http://dx.doi.org/10.1215/9780822386179

Salomon, F. 2008. Late Khipu Use. In Baines, J., Bennet, J. and Houston, S. D. (eds), The Disappearance of Writing Systems: Perspectives on literacy and communication. London: Equinox, 285-310.

Salomon, F., Brezine, C. and Falcón Huayta, V. 2006. Los khipus de Rapaz en casa: Un complejo administrativo-ritual centroperuano. Revista Andina 43: 59-92.

Sempat Assadourian, C. 2002. String Registries: Native accounting and memory according to the Colonial sources. In Quilter, J. and Urton, G. (eds), Narrative Threads: Accounting and recounting in Andean khipu. Austin, TX: University of Texas Press, 119-150.

Shady, R., Narváez, J. and López S. 2000. La antigüedad del uso del quipu como escritura: Las evidencias de la huaca San Marcos. Boletín del Museo de Arqueología y Antropología (Lima) 3(10): 2-23.

Soto Flores, F. 1990 [1950-1951]. Los kipus modernos de la localidad de Laramarca. In Mackey, C., Pereyra, H., Radicati, C., Rodríguez, H. and Valverde, O. (eds), Quipu y yupana: Colección de escritos. Lima: CONCYTEC, 183-190.

Tello, J. and Miranda P. 1923. Wallallo: Ceremonias gentílicas realizadas en la región cisandina del Perú central. Inca: Revista Trimestral de Estudios Antropológicos 1(2): 475-549.

Thomson, S. 2002. We Alone Will Rule: Native Andean politics in the age of insurgency. Madison: University of Wisconsin Press.

Tufte, E. 1983 The Visual Display of Quantitative Information. Cheshire, CT: Graphics Press.

Urton, G. 2001. A Calendrical and Demographic Tomb Text from Northern Peru. Latin American Antiquity 12(2): 127-147. DOI: http://dx.doi.org/10.2307/972052

Urton, G. 2003. Signs of the Inka Khipu: Binary coding in the Andean knotted-string records. Austin: University of Texas Press.

Urton, G. 2007. Los khipus de la Laguna de los Cóndores. Lima: Nuevas Imágenes, S. A.

Wassén, H. 1990 [1931]. El antiguo abaco peruano según el manuscrito de Guaman Poma. In Mackey, C., Pereyra, H., Radicati, C., Rodríguez, H. and Valverde, O. (eds), Quipu y yupana: Colección de escritos. Lima: CONCYTEC, 205-218.

Wassmann, J. 1991 [1982]. The Song to the Flying Fox: The public and esoteric knowledge of the important men of Kandingei about totemic songs, names, and knotted cords (Middle Sepik, Papua New Guinea) (translated by D. Stephenson) (Apwitihire: Studies in Papua New Guinean Music, 2). Boroko, Papua New Guinea: Cultural Studies Division, the National Research Institute. 